GONZÁLEZ, Diego. "El delito de parricidio: consideraciones críticas sobre sus últimas reformas".

Polít. crim. Vol. 10, № 19 (Julio 2015), Art. 7, pp. 192-233.

[http://www.politicacriminal.cl/Vol_10/n_19/Vol10N19A7.pdf]

\title{
El delito de parricidio: consideraciones críticas sobre sus últimas reformas.*
}

The crime of parricide: critical considerations regarding the latest reforms.

\author{
Diego González Lillo \\ Profesor ayudante de Derecho penal de la Universidad de Valparaíso \\ diego.gonzalezlillo@gmail.com
}

\section{Resumen}

El artículo tiene por objeto analizar, desde una perspectiva crítica, la configuración actual del parricidio en Chile. Para ello, primero se ofrecerá un breve repaso histórico de la figura, resaltando las razones dogmáticas que han llevado a su supresión en el Derecho comparado. Acto seguido, desde un punto de vista conceptual y normativo, se analizan las categorías de violencia de género, violencia doméstica y femicidio, así como la forma en que éstas han penetrado en la estructura típica del artículo 390 del Código penal chileno. A partir de ello, se expondrá la crítica de dos aspectos relativos a los sujetos del delito: la indeterminación de la noción de conviviente y la extensión del tipo a los ex cónyuges y ex convivientes. Finalmente, se revisarán otras consideraciones de índole político-criminal que desaconsejan seguir ampliando la figura.

Palabras clave: Parricidio, femicidio, conviviente, Derecho penal simbólico.

\begin{abstract}
This article aims to analyze, from a critical perspective, the current configuration of parricide in Chile. For this, first a brief historical overview of the crime will be presented, highlighting the theoretical reasons that have led to its elimination from Comparative law. Then, from a conceptual and normative perspective, the categories of gender violence, domestic violence, and femicide will be analyzed, as well as the manner in which they have penetrated the structure of article 390 of the Chilean Penal Code. From this, the critique of two aspects relative to subjects of this crime will be discussed: the indeterminacy of the notion of cohabiting partner and the increase in scope of the norm to include former spouses and former cohabitants. Lastly, other criminal policy considerations that discourage a further expansion of the crime will be reviewed.
\end{abstract}

Key words: Parricide, femicide, cohabiting partner, symbolic criminal law.

\footnotetext{
* Agradezco los valiosos comentarios formulados por los profesores José Luis Guzmán Dalbora y Laura Mayer Lux. Los errores u olvidos subsistentes son, desde luego, de mi entera responsabilidad.
} 
GONZÁLEZ, Diego. "El delito de parricidio: consideraciones críticas sobre sus últimas reformas".

\section{Introducción}

A contrapelo de la marcada directriz comparada que ordena la desaparición del parricidio, actualmente se presenta otra, consistente en extender el aparato punitivo a hechos que tradicionalmente lindaron en la esfera de lo privado, o bien en intensificar su aplicación respecto de los ya tipificados. Precisamente la primera parte de este trabajo pretenderá exponer las razones y los motivos que se esconden en una y otra tendencia. Es decir, por qué el parricidio se deroga en la mayoría de los países y, sin embargo, prolifera y se renueva en forma continua la legislación relativa a las violencias de género e intrafamiliar.

Al abrigo de una Política criminal orientada a mitigar la violencia dentro de la pareja, el Derecho penal asiste a un proceso global de expansión. No obstante, el caso chileno reviste cierta peculiaridad. En efecto, pese a que nuestro ordenamiento tomó parte en este ensayo durante los años noventa, al establecer normas especiales sobre procedimiento y sanciones relativas a actos de violencia intrafamiliar, las decisiones más importantes en la materia también se han introducido por la vía de ampliar el ámbito subjetivo de aplicación del parricidio. Primero, con la Ley No 20.066, que incluyó al conviviente como sujeto pasivo y, pronto, mediante la Ley $\mathrm{N}^{\mathrm{o}} 20.480$, que incorporó a quien fue cónyuge o conviviente del hechor.

Buena parte de este trabajo se concentrará en revelar los defectos que acusan tales enmiendas. La situación del conviviente como posible sujeto de parricidio, y la actual ausencia de un estatuto legal que lo regule, hará que el análisis derive en denunciar una eventual transgresión del principio de determinación. En cambio, respecto de la inclusión de las relaciones terminadas, directamente se cuestionará su justificación material. Por este motivo, el fundamento de la agravación del parricidio recién será examinado conjuntamente con dicho tema.

Después de estudiados estos puntos, se establecerán las relaciones existentes entre ciertos aspectos de la normativa nacional y el denominado Derecho penal simbólico.

\section{Generalidades y delimitación del tema.}

\subsection{Origen y decurso del parricidio en el Derecho comparado.}

El parricidio hunde sus raíces en los albores de la humanidad, siendo incluso considerado "el crimen antiguo por antonomasia"1. Del desprecio que despierta dar muerte al padre se ocupan ya las primeras legislaciones de Babilonia, Egipto, China y Grecia; aunque fue en Roma donde alcanzó una particular trascendencia cultural y más brutal conminación ${ }^{2}$. Pese a que aún existen opiniones divorciadas sobre su origen etimológico ${ }^{3}$, se ha acreditado que

\footnotetext{
${ }^{1}$ QUINTANO RIPOLLÉS, Antonio, Tratado de la Parte especial del Derecho penal, t. I, vol. 1, $2^{\mathrm{a}}$ ed. actualizada por GIMBERNAT, Enrique, Madrid: Revista de Derecho Privado, 1972, p. 121.

${ }^{2}$ El denominado culleum, consistente en atar al condenado a un saco de cuero y arrojarlo al mar junto con un perro, un gato o gallo, un mono y una serpiente, vivos. El carácter de atentado contra los Dioses atribuido desde antiguo al delito, explicaba el marcado corte expiatorio de su pena.

${ }^{3}$ Según algunos proviene de pater, mientras para otros su etimología se encuentra en parens.
} 
Polít. crim. Vol. 10, № 19 (Julio 2015), Art. 7, pp. 192-233.

[http://www.politicacriminal.cl/Vol_10/n_19/Vol10N19A7.pdf]

la versión romana más primitiva reconocía un único sujeto pasivo: el paterfamilias. Habida cuenta de su singular significación social, el padre de familia estuvo incluso dotado de la facultad de matar a sus descendientes, o bien, a su mujer, cuando ésta incurría en adulterio o embriaguez habitual. Posteriormente, con el propósito de limitar la venganza privada, se creó un órgano especial para el conocimiento de los delitos más graves -los quaestores parricidii-, mientras el parricidium se vio ampliado a la sazón hasta captar la muerte de cualquier ciudadano libre 4 . Solamente con la Lex Pompeia de Parricidiis cobró cuerpo en Roma una acepción más cercana a la idea moderna del delito, abarcando la muerte de consanguíneos ad infinitum, colaterales hasta el cuarto grado, cónyuges, desposados y ciertos parientes por afinidad. En razón de semejante extensión, los prácticos medievales hicieron el distingo entre parricidio propio e impropio, que hasta hoy se repite ${ }^{5}$.

El transcurso de la alta Edad media no aparejó mayores cambios, conservándose los elementos que de Roma se heredaron. Sólo destaca un célebre código recopilatorio, dictado por los visigodos, y comprensivo de los puntos cardinales del delito: el Liber Iudiciorum. Más adelante, en la época de los fueros municipales, persistió la escasez de cuerpos normativos dedicados al parricidio, pero los pocos que lo nombraron partieron por equipararlo a la infracción de vínculos de lealtad o señorío ${ }^{6}$. En lo que a la aportación canónica se refirió, la más célebre fue la de "incluir decididamente en la modalidad parricida la del conyugicidio, en plano de perfecta igualdad y no de privilegio al varón.”,7.

Modernamente, fueron Las Partidas las que informaron sobre este delito a los Derechos de los Reinos Hispánicos, en lo que conservó la esencia del concepto romano (incluso la pena) y constituyó el insumo con que hubo de trabajar la codificación. Así, el parricidio fue recogido por los Códigos napoleónico, imperial alemán, prusiano y español, entre varios que representaron mayoría. Otros cuerpos sólo consagraron un homicidio cualificado por el parentesco, tal fue el caso de los ejemplares italiano, chino y argentino. Excepcionalmente, los ordenamientos anglosajón y norteamericano optaron por prescindir de la figura.

En lo que hace al Código penal chileno, el parricidio recibió consagración positiva en la versión original de 1874, regulándose, como hasta ahora, en su artículo 390. Los comisionados usaron de modelo al Código penal español de 1848 comentado por Pacheco, aunque en ciertos aspectos relevantes se alejaron de su arquetipo normativo ${ }^{8}$.

\footnotetext{
${ }^{4}$ TORRES AGUILAR, Manuel, El parricidio: del pasado al presente de un delito, Madrid: Editoriales de Derecho, 1991, pp. 27 y ss.

${ }^{5}$ El parricidio propio designa la muerte del padre o un ascendiente, de parte del hijo u otro descendiente. El impropio, en cambio, incluye las restantes fórmulas, es decir, el libericidio, conyugicidio y familicidio. Véase, por todos, GUALLART DE VIALA, Alfonso, "Parricidio", en: Nueva Enciclopedia Jurídica, t. XVIII, Barcelona: Seix, 1986, pp. 927-944, p. 929.

${ }^{6}$ La inapropiada asociación permitió que se incluyera, dentro del delito, figuras tales como la muerte del señor por el siervo, el homicidio entre socios o compañeros y atentar contra la vida del huésped, entre otras modalidades. Cfr. TORRES, El parricidio, cit. nota no 4, pp. 119-122.

${ }^{7}$ QUINTANO, Tratado de la Parte especial, cit. nota ${ }^{\circ} 1$, p. 126.

${ }^{8}$ Nuestro legislador no incluyó a la filiación adoptiva. Contempló como eximente los casos en que el marido daba muerte a su mujer tras sorprenderla en adulterio, cuando en España sólo servía de atenuante. Se distanció también al exigir expresamente en el parricida conocimiento de las relaciones que lo ligan con el paciente. Cfr. Código penal de la República de Chile y Actas de las sesiones de la Comisión redactora del Código penal chileno, dirección y estudio preliminar de RIVACOBA, Manuel, Valparaíso: Edeval, 1974, p. 398.
} 
GONZÁLEZ, Diego. "El delito de parricidio: consideraciones críticas sobre sus últimas reformas".

Desde ya varias décadas, sin embargo, la tendencia que sigue el parricidio en el escenario comparado es la de su desaparición. Ante la paladina dificultad que entraña justificar tan ríspida punición, diversas legislaciones han terminado por someterlo a las reglas generales del homicidio, sea que se conserve o no una circunstancia modificativa de parentesco. De esta suerte, se atendieron las voces doctrinales que reclamaban su abrogación.

Así pues, desde un plano criminológico había perdido sentido su tipificación especial. Ciertamente, su origen proviene de relaciones íntimas y cerradas, propio de sociedades o grupos primitivos, y producto de la tensión de esas mismas formas de relación ${ }^{9}$. Este carácter mágico-religioso carece de correlato actual, luego de haberse evaporado buena parte de su sustentación sociológica. Palmario ejemplo de ello constituyen los radicales cambios que ha experimentado la noción de familia, en circunstancias que ni el parentesco ni el matrimonio son ya factores inequívocos a la hora de definir sus contornos. Por esto, la supresión del parricidio es reconocimiento de desarrollo cultural y a la vez desapego respecto de aquel trasfondo irracional y sacro que durante siglos tiñó indeleblemente al delito.

De otra parte, la idea de considerar al parentesco por sí como circunstancia agravatoria en los crímenes contra la vida, últimamente había sido puesta en tela de juicio, cuestionándose si acaso se justifica una valoración tan diversa de la aplicable a delitos patrimoniales ${ }^{10}$.

La modalidad española del conyugicidio hubo de soportar críticas adicionales. Ya Alejandro Groizard se había resuelto contrario a su equiparación con el parricidio propio, dado que las causas que contribuyen a turbar la paz del matrimonio distan mucho de aquellas que desencadenan las muertes entre consanguíneos ${ }^{11}$. De esta convicción también participó Quintano, quien demandó la supresión de este pseudo-parricidio, por entender que el conyugicida reviste características disímiles en lo psíquico y moral respecto del auténtico parricida, resultando artificiosa toda asimilación ${ }^{12}$. Ángel Torío López, otro ibérico, protestó décadas atrás que en la muerte entre cónyuges no se considera la excitación profunda del autor como elemento reductor de culpabilidad, y, por lo mismo, propugnaba, si no la abolición del delito, cuando menos la incorporación de fórmulas circunstanciadas de homicidio pasional ${ }^{13}$.

\footnotetext{
${ }^{9}$ BUSTOS RAMÍREZ, Juan, Manual de Derecho penal: Parte especial, $2^{\mathrm{a}}$ ed., Barcelona: Ariel, 1991, p. 28. Cfr. asimismo SANZ MORÁN, Ángel, "Presupuestos para la reforma de los delitos contra la vida", ADPCP, t. XLVIII, fasc. III (1995), pp. 783-848, pp. 814 y ss.

${ }^{10}$ Como se sabe, diversos ordenamientos contemplan en materia de hurtos y defraudaciones una excusa legal absolutoria en favor de parientes y cónyuges, razón por la cual se recusa como anacrónico e incoherente el sentido de la agravante. Así, ESPINOZA, Edilberto, “Se debe suprimir el parricidio del Código penal peruano?", Revista jurídica del Perú, no 61 (2005), pp. 77-91, p. 82. Cfr. GANZENMÜLLER, Carlos; ESCUDERO, José; FRIGOLA, Joaquín, Homicidio y asesinato, Barcelona: Bosch, 1996, pp. 179-180.

${ }^{11}$ GROIZARD, Alejandro, Código penal de 1870, concordado y comentado, t. IV, Salamanca: Esteban Hermanos Impresores, 1897, pp. 339-341.

${ }_{12}^{12}$ QUINTANO, Tratado de la Parte especial, cit. nota n ${ }^{\circ} 1$, pp. 147-148.

${ }^{13}$ TORÍO LÓPEZ, Ángel, "Estudio de la reforma de los delitos contra la vida (parricidio-asesinato)", en: RODRÍGUEZ DEVESA, José (coord.), Repercusiones de la Constitución en el Derecho penal, Bilbao: Universidad de Deusto, 1983, pp. 77-114, p. 83.
} 
Polít. crim. Vol. 10, № 19 (Julio 2015), Art. 7, pp. 192-233.

[http://www.politicacriminal.cl/Vol_10/n_19/Vol10N19A7.pdf]

Así las cosas, el parricidio sufrió un proceso de derogación masiva durante el siglo pasado. Dentro de los países europeos que se han desprendido del tipo cuentan Alemania, Holanda, Suiza, Polonia, Finlandia, Grecia, Noruega y Dinamarca. En cuanto a España, el Código de 1995 también optó por prescindir de él, y pese a que se barajó la alternativa de utilizar el parentesco como circunstancia agravante, se prefirió asignarle un carácter mixto.

A contramano de la experiencia comparada, en Chile, las pocas propuestas derogatorias del parricidio han fracasado ${ }^{14} \mathrm{y}$, en cambio, las recientes modificaciones no han hecho más que ampliar su esfera subjetiva de aplicación ${ }^{15}$. Los motivos y el fondo de tales reformas simbolizan un intento por embestir las denominadas violencias intrafamiliar y de género, ensayo igualmente emprendido por otros ordenamientos, aunque no siempre en idéntica directriz. Por tanto, en esta específica partida, la asunción de protagonismo del instrumento punitivo nace y se explica en cierto contexto histórico e ideológico. El repaso breve de estos contenidos, y de la prolífica legislación extranjera sobre la materia, favorecerá una comprensión cabal de la configuración actual del parricidio en el Código penal chileno.

\subsection{Violencia intrafamiliar, femicidio y figuras afines en la legislación extranjera.}

Convengamos que el fenómeno de la violencia doméstica no es precisamente nuevo, sino que reciente es la atención volcada sobre él. En efecto, sus orígenes se pierden en el sistema feudal y su estructura reforzada del patriarcado, la expulsión de las mujeres de los gremios y la difusión del paganismo, entre otros tantos factores ${ }^{16}$. El sometimiento de las mujeres a un escenario de subyugación material y maltrato permaneció prácticamente invariable hasta el siglo XX, momento en que la guerra y la crisis económica favorecieron su inserción a los mundos laboral y universitario. En la última treintena del siglo pasado ya habían adquirido cierta independencia económica, social y jurídica, que, sumada a la toma de conciencia sobre sus derechos, permitió iniciar su resistencia a sufrir tales abusos en silencio ${ }^{17}$. Este discurso se potenció sobremanera con la copiosa bibliografía proveniente de la criminología feminista y hoy en día sigue siendo un movimiento en franca expansión.

Desde un prisma conceptual, urge precisar que violencia de género y violencia doméstica no son lo mismo y ninguna es presupuesto de la otra ${ }^{18}$. Según la mayoría, lo determinante para calificar una agresión como violencia de género es que ésta se ejerza contra una mujer

\footnotetext{
${ }^{14}$ En el año 2001, un grupo de diputados presentó ante la Cámara un proyecto de ley tendiente a suprimir el parricidio, el Boletín 2661-18, archivado un cuatrienio más tarde. En 2005 se propuso al entonces Presidente de la República, Ricardo Lagos Escobar, un anteproyecto de Código penal, elaborado por la Comisión Foro Penal, en el que también se prescindía del parricidio como figura autónoma.

${ }^{15}$ Hasta antes del año 2005, el artículo 390 solamente había sufrido enmiendas atingentes a su penalidad. Con la Ley $\mathrm{N}^{\circ} 17.266$ de 1970 , se estableció el presidio perpetuo como pena alternativa a la de muerte, y luego, en el año 2001, la Ley $\mathrm{N}^{\circ} 19.734$, eliminó toda referencia al extremo suplicio.

${ }^{16}$ ZAFFARONI, Eugenio, "El discurso feminista y el poder punitivo", en: ÁVILA, Ramiro; SALGADO, Judith; VALLADARES, Lola (Compiladores), El género en el Derecho. Ensayos críticos, Quito: V\&M Gráficas, 2009, pp. 321-334, p. 326.

${ }^{17}$ ÁLVAREZ PRIETO, Luis, "La violencia de género en España y su repercusión jurídica", Revista general de Derecho canónico y Derecho eclesiástico del Estado, $\mathrm{n}^{\mathrm{o}} 4$ (2004), pp. 2-4, en: http://www.iustel.com/v2/revistas/detalle_revista.asp?id_noticia=402152 [visitado el 12.11.2014].

${ }^{18}$ CORCOY BIDASOLO, Mirentxu, "Problemática jurídico-penal y político-criminal de la regulación de la violencia de género y doméstica", Revista de Derecho (Valparaíso), nº XXXIV (2010), pp. 305-347, p. 307.
} 
GONZÁLEZ, Diego. "El delito de parricidio: consideraciones críticas sobre sus últimas reformas".

por el mero hecho de serlo ${ }^{19}$. Lo doméstico, en cambio, se define por un elemento contextual. Con todo, visto que en la mayoría de los casos el paciente es una mujer, la arenga feminista aplicó su discurso con referencia a la primera clase de violencia indicada $^{20}$. Este aparato argumentativo, refractario de la desigualdad estructural que mantiene la sociedad, solicita del Derecho penal las funciones de proteger, igualar y dotar de mayores poderes a la mujer ${ }^{21}$. El alcance internacional de un movimiento que deposita una especial ilusión en el control penal, ha tenido correspondencia legislativa mediante el abandono de la neutralidad de sexo en algunos tipos penales. El reconocimiento del femicidio constituye su triunfo más reciente.

El femicidio es un neologismo que carece de asidero en la lengua castellana. Proveniente de la voz inglesa femicide -acuñada por la socióloga Diana Russell-, últimamente pretende designar el homicidio de mujeres por el hecho de ser tales. No obstante, según su empleo inicial, el término aludía invariablemente a cualquier acto de violencia física, psíquica o sexual dirigido contra una mujer, con el objeto de herirla o degradarla, amenazando su capacidad de controlar sus relaciones íntimas ${ }^{22}$. Esta diversidad de sentido remató pronto en la elaboración de subcategorías muy variadas entre $s^{23}$. La volubilidad e imprecisión del término quizás se deba a que sus principales contribuciones provienen de ciencias sociales que, no menos importantes, están exentas de las exigencias de taxatividad que se imponen a la jurídica. Esta nota explicaría la tendencia a requerir elementos enteramente exógenos al delito -la misoginia y la impunidad del hechor, por ejemplo-, oscureciendo todavía más semejante galimatías.

\footnotetext{
${ }^{19}$ Véase, por muchos, ALONSO ÁLAMO, Mercedes, "Protección penal de la igualdad y derecho penal de género", Cuadernos de Política Criminal, no 95 (2008), pp. 19-52, p. 27. Con todo, se trata de un concepto sumamente vaporoso, y de cualquier forma excepcional, pues cuesta imaginar que en cada caso el agente sea un misógino, que detesta la sola existencia de la mujer. Damos razón por ello a quienes caracterizan estos hechos como un sometimiento de la voluntad del paciente por parte de su agresor. Así, PERALTA, José, "Homicidios por odio como delitos de sometimiento (Sobre las razones para agravar el femicidio, el homicidio por odio a la orientación sexual y otros homicidios por odio)", InDret, $\mathrm{n}^{\circ} 4$ (2013), pp. 10-11.

${ }^{20}$ LARRAURI, Elena, Criminología crítica y violencia de género, Madrid: Trotta, 2007, p. 18.

${ }^{21}$ LARRAURI, Criminología, cit. nota $n^{\circ}$ 20, pp. 18-19. Aunque es dudoso que la violencia de género sea sólo causa de la desigualdad económica, ya que el fenómeno no discrimina entre capas sociales, y tampoco varía mucho según el grado de desarrollo del país. Cfr. MAQUEDA, María Luisa, "La violencia de género. Entre el concepto jurídico y la realidad social", RECPC, $\mathrm{n}^{\mathrm{o}} 2$ (2006), p. 13, en: http://criminet.ugr.es/recpc/08/recpc08-02.pdf [visitado el 12.11.2014]; véase también CORCOY, "Problemática", cit. nota $\mathrm{n}^{\circ} 18$, p. 345.

${ }^{22}$ RUSSELL, Diana; RADFORD, Jill, Femicide: The politics of woman killing, New York: Twayne Publishers, 1992, p. 3.

${ }^{23}$ Así, se ha denominado feminicidio al conjunto de delitos de lesa humanidad cometidos contra mujeres, cuyo rasgo común es la inoperancia estatal que los ensombrece. Se distingue asimismo entre femicidio íntimo y no íntimo; donde el primero refiere al homicidio cometido por un hombre contra una mujer que es o ha sido su cónyuge o concubina, y el segundo, al hecho de sangre perpetrado por un hombre contra una mujer con la que no mantenía relación ninguna. Otros separan las muertes violentas de mujeres por conductas delictivas, respecto de aquellas muertes evitables, pero no criminalizadas, incluyendo en ellas los decesos derivados de partos en deplorables condiciones higiénicas, los sufridos por abortos caseros o, por VIH, cuando la mujer no puede negociar con sus parejas o clientes el uso de preservativo, etc. Cfr. LAURENZO, Patricia, "Apuntes sobre el feminicidio", Revista de Derecho penal y Criminología, no 8 (2012), pp. 119-143, pp. 123 y ss.
} 
Polít. crim. Vol. 10, № 19 (Julio 2015), Art. 7, pp. 192-233.

[http://www.politicacriminal.cl/Vol_10/n_19/Vol10N19A7.pdf]

Dicho lo cual, pasemos revista de los recursos normativos con que algunos ordenamientos han perseguido aplacar la violencia doméstica o particularmente contra la mujer ${ }^{24}$. Uno de los países pioneros ha sido España, con sucesivas enmiendas al Código penal. En singular conjugación de expansión típica y severidad punitiva, varios delitos revelan hoy una punición mayor cuando la ofendida es la esposa o mujer ligada con el agente por una análoga relación de afectividad, aun sin convivencia ${ }^{25}$. Otras naciones europeas, como Suiza, Suecia e Italia, también han hecho suya una regulación similar ${ }^{26}$. Entre los países latinoamericanos, las legislaciones de Brasil, República Dominicana, Honduras, Bolivia, Venezuela, Argentina y México, se hacen eco de esta situación, ya sea ampliando el catálogo de delitos relativos a la violencia doméstica, exasperando el castigo de homicidios cometidos en dicho contexto, o ambas cosas a la par $^{27}$. Por emplear un nomen iuris distinto, mención particular merecen los casos de Costa Rica, Guatemala, Nicaragua y Perú ${ }^{28}$.

Mediante el análisis de las Leyes № 20.066 y № 20.480, toca finalmente analizar cómo estas nociones han penetrado en la normativa vernácula, y cuál ha sido su repercusión en la estructura típica del artículo 390 del Código penal chileno.

\footnotetext{
${ }^{24}$ Haciendo reserva de un plexo de instrumentos internacionales con superlativa importancia en la materia. Destacan: la "Convención para la eliminación de todas las formas de discriminación contra las mujeres", adoptada en 1979 por la ONU; la "Convención Interamericana para prevenir, sancionar y erradicar la violencia contra la mujer", de 1994; la "Declaración de Naciones Unidas sobre eliminación de la violencia contra la mujer", de 1999; y la "Convención del Consejo de Europa sobre prevención y lucha contra la violencia contra las mujeres y la violencia doméstica", de 2011.

${ }^{25}$ Así sucede en los delitos de lesiones agravadas (artículo 148); maltratos físicos y psíquicos (artículo 153); amenazas de un mal no constitutivo de delito (artículo 171); coacciones (artículo 172) y tortura (artículo 173). La constitucionalidad de esta cláusula encendió subidas críticas en la doctrina española, por entenderse que introdujo una afectación no razonable a los principios de igualdad y proporcionalidad. Véase TAMARIT SUMALLA, Josep, "De las lesiones", en: QUINTERO OLIVARES, Gonzalo (Dir.), Comentarios a la Parte especial del Derecho penal, $6^{\mathrm{a}}$ ed., Navarra: Aranzadi, 2007, pp. 101-143, pp. 117 y ss.

${ }^{26}$ Véanse los artículos 123, 126 y 180 del Código penal helvético; el capítulo cuarto del Código penal sueco; y el artículo 609-ter, 5-quater, del Código penal italiano.

${ }^{27}$ Véanse los artículos 129 del Código penal de Brasil; 179-A del Código penal de Honduras; 303-4 No 7 del Código penal de República Dominicana; 5 de la Ley contra la violencia en la familia o doméstica de Bolivia; 4 de la Ley sobre la Violencia contra la mujer y la familia de Venezuela; 80 del Código penal argentino; y 148 bis del Código penal mexicano.

${ }^{28}$ En Costa Rica, la Ley $\mathrm{N}^{\circ} 8.589$, consagra el femicidio en su artículo 21, castigando con la misma pena que el homicidio calificado "a quien de muerte a una mujer con la que mantuvo una relación de matrimonio, en unión de hecho declarada o no". En tanto que en Guatemala, la "Ley contra el femicidio y otras formas de violencia contra la mujer", en su artículo 6, fija un aparatosamente amplio delito de femicidio, castigando a través de él, a quien da muerte a la mujer con que pretendió infructuosamente establecer una relación de pareja; con la que mantenía relaciones de intimidad, noviazgo, amistad, o de carácter laboral; cuando comete el delito por misoginia o mediante mutilación de la víctima, entre varios otros supuestos. En términos prácticamente idénticos a los de la normativa guatemalteca, en Nicaragua se tipifica el femicidio en el artículo 9 de la "Ley integral contra la violencia hacia las mujeres". El Código penal peruano, por su lado, ha sufrido sucesivas modificaciones. Primero, en el año 2011, se consagró el feminicidio en tanto modalidad impropia de parricidio en el inciso tercero del artículo 107, en los siguientes términos: "Si la víctima del delito descrito es o ha sido la cónyuge o la conviviente del autor, o estuvo ligada a él por una relación análoga, el delito tendrá el nombre de feminicidio". Dos años más tarde se derogó dicha cláusula, acuñándose un tipo autónomo de feminicidio, en lo que es el actual artículo 108-B, que también delata una regulación casuística.
} 
GONZÁLEZ, Diego. "El delito de parricidio: consideraciones críticas sobre sus últimas reformas".

\subsection{Las Leyes de reforma $\mathbf{N}^{\circ} \mathbf{2 0 . 0 6 6}$ y $\mathbf{N}^{\circ} \mathbf{2 0 . 4 8 0}$. Esbozo de la estructura típica actual del parricidio en Chile.}

Con fecha 7 de octubre de 2005, se publicó en Chile la Ley $N^{\circ}$ 20.066, también denominada "Nueva Ley de Violencia Intrafamiliar". Entre las novedades de dicha normativa, se encuentra el delito de maltrato habitual, que plasma su artículo 14. Este precepto, que en opinión de algunos constituye una "tipificación expresa, aunque compleja, de las vías de hecho" ${ }^{29}$, representó una patente criminalización de la violencia intrafamiliar, visto que la competencia de los tribunales de familia quedó restringida considerablemente a eventos residuales. Entretanto, el artículo 9 estableció un catálogo de medidas cautelares aunque también operan como pena accesoria-, cuyo quebrantamiento, conforme al artículo 10, configura el delito de desacato. En materia de lesiones, esta ley dispuso aplicar la agravante específica del artículo 400 del Código penal a todos los casos en que la víctima sea una de las personas enumeradas en su artículo 5. Y en lo que nos interesa, significó una importante modificación al tipo de parricidio, tras integrar al conviviente como posible sujeto, amén de eliminar la trasnochada distinción entre hijos legítimos e ilegítimos.

Ahora bien, no obstante los profundos cambios que significó con relación a la normativa anterior, la Ley N 20.066 se siguió reputando insuficiente. Así, al cabo de un corto tiempo, un grupo de diputados presentó un proyecto de ley -Boletín 4937-18, de 3 de abril de 2007- de cara a modificar el Código penal y el Decreto Ley № 321 de 1925 sobre "Libertad condicional de los penados". Dentro de las consideraciones que propugnaban un incremento en las penas, se indicó, entre otros motivos, los hechos de excesiva violencia dentro de la pareja que conmocionan a la opinión pública y la circunstancia de que los agresores se vean favorecidos por atenuantes o beneficios que les permitan rebajar sus penas o minimizar su cumplimiento efectivo ${ }^{30}$. La propuesta base proyectó reformas legales en tres sentidos: incorporar el delito de femicidio, entendiendo por tal el homicidio en que la víctima sea la cónyuge, conviviente o cualquier mujer con la que el agresor está o haya estado ligado por alguna relación análoga afectiva; disminuir las posibilidades de aplicar la circunstancia atenuante $5^{\mathrm{a}}$ del artículo 11; e impedir el acceso a la libertad condicional para condenados por delitos graves de connotación familiar ${ }^{31}$. Luego de un intrincado debate legislativo, consecuencia natural de la atosigante presión social que lo rodeó, la iniciativa remató en la Ley $\mathrm{N}^{\mathrm{0}} 20.480$, publicada el día 18 de diciembre de $2010^{32}$.

\footnotetext{
${ }^{29}$ VAN WEEZEL, Alex, "Lesiones y violencia intrafamiliar”, Revista Chilena de Derecho, vol. XXXV, n⿳ 2 (2008), pp. 223-259, p. 242.

${ }^{30}$ BIBLIOTECA DEL CONGRESO NACIONAL DE CHILE, Historia de la Ley $N^{o}$ 20.480, pp. 4-5, en: http://www.leychile.cl/Navegar/scripts/obtienearchivo?id=recursoslegales/10221.3/27994/1/HL20480.pdf [visitado el 12.11.2014].

${ }^{31}$ BIBLIOTECA, Historia de la Ley $N^{o} 20.480$, cit. nota ${ }^{\circ} 30$, pp. 5-6.

${ }^{32}$ Especialmente problemático resultó el acuerdo sobre la esfera subjetiva de aplicación del nuevo femicidio. Según lo dispuesto originalmente, el delito comprendía "la muerte de la mujer con la que el femicida esté o haya estado ligado como cónyuge, conviviente o a través de cualquier otra relación afectiva". La Comisión de familia consideró, acertadamente, que la expresión "relación afectiva" tenía un alcance desmesuradamente amplio, por lo que fue suprimida. En su hora también operó una indicación sustitutiva del Ejecutivo, que agregaba como sujeto activo "al que mate a persona con la que tiene un hijo en común", luego rechazada. Presentado el informe de la primera Comisión de Constitución, se excluyó por igual la sugerencia consistente en agregar a quienes han cesado efectivamente su vida en común con, a lo menos, tres años de anterioridad a
} 
Polít. crim. Vol. 10, № 19 (Julio 2015), Art. 7, pp. 192-233.

[http://www.politicacriminal.cl/Vol_10/n_19/Vol10N19A7.pdf]

Al igual que la anterior, esta ley también acompañó reformas en varias materias relevantes. Por ejemplo, agregó el estado de necesidad exculpante al numeral 11 del artículo 10 del Código penal, y dispuso ciertas modificaciones en los delitos contra la libertad sexual, agregando otras tantas al régimen de medidas cautelares de la Ley $\mathrm{N}^{\mathbf{0}}$ 20.066. No obstante, su principal efecto fue la inclusión de nuevas hipótesis de parricidio y una tipificación expresa del femicidio en Chile. Actualmente, el artículo 390 reza del siguiente modo:

"El que, conociendo las relaciones que los ligan, mate a su padre, madre o hijo, a cualquier otro de sus ascendientes o descendientes o a quien es o ha sido su cónyuge o su conviviente, será castigado, como parricida, con la pena de presidio mayor en su grado máximo a presidio perpetuo calificado.

Si la víctima del delito descrito en el inciso precedente es o ha sido la cónyuge o la conviviente de su autor, el delito tendrá el nombre de femicidio".

Como primer comentario, consignemos que, a pesar de la declaración simbólica estampada en el inciso segundo, en propiedad, la nueva figura no responde a lo que corrientemente se entiende por femicidio. Configurada como está, la agravación se verifica en razón del vínculo matrimonial o de concubinato que existe o existió entre el hechor y la víctima, cual dato puramente formal. Por ello, a nuestro juicio, no es posible desprender exigencias adicionales, como requerir móviles discriminatorios de parte del hechor o que el delito sea consecuencia de la violencia de género ejercida contra la víctima ${ }^{33}$. Esta conclusión aparece reforzada por la peculiaridad de que, según el tenor del inciso segundo, no es necesario que el sujeto activo sea un varón ${ }^{34}$. Así, la cláusula incorporada, cuya referencia se agota en el contexto y las relaciones que median entre los sujetos, acusa el empleo de una técnica propia de los tipos de violencia intrafamiliar, olvidando por completo que la categoría del femicidio se ideó para subrayar el sexo de quién sufre la muerte, pero también el motivo por el cual la padece ${ }^{35}$. Habida cuenta de este cariz objetivo, no faltara quien se pregunte si estos hechos pueden agravarse merced la circunstancia prevista en el artículo $12 \mathrm{~N}^{\mathrm{o}} 21^{36}$.

la ejecución del delito, salvo que existan hijos comunes. En fin, únicamente después de crearse una Comisión mixta, se aprobó, eso sí por unanimidad, la enmienda al artículo 390.

${ }^{33}$ A contrapelo de lo que entienden MATUS, Jean Pierre; RAMÍREZ, María Cecilia, Lecciones de Derecho penal chileno: Parte especial, t. I, $3^{\text {a }}$ ed., Santiago: LegalPublishing, 2014, p. 80. En su opinión, con esta figura se incorporó entre nosotros la idea de lo que modernamente se denomina violencia de género, dando así el Estado chileno cumplimiento a sus obligaciones internacionales en orden a prevenir, sancionar y erradicar la violencia contra la mujer.

${ }^{34}$ La relación de convivencia — que no la de matrimonio, desde luego- perfectamente puede darse entre dos mujeres, $\mathrm{y}$, en este sentido, si una compañera da muerte a la otra, podría ser castigada como autora de femicidio. Así también VARGAS, Tatiana; SANTIBÁÑEZ, María Elena, "Reflexiones en torno a las modificaciones para sancionar el femicidio y otras reformas relacionadas (Ley $\mathrm{N}^{\circ}$ 20.480)", Revista Chilena de Derecho, vol. XXXVIII, n 1 (2011), pp. 193-207, p. 205. En cambio, según TALADRÍZ, María José, "Decisiones judiciales en el ámbito penal acerca del concepto 'convivencia"', Revista de Ciencias penales, vol. XLI, $n^{\circ} 4$ (2014), pp. 79-102, pp. 98-99, dado que la Ley $\mathrm{N}^{\circ} 20.480$ reformuló el delito de parricidio con una visión de género, sólo "pareciera ser posible perseguir y sancionar como femicida al hombre que mata a quien es o ha sido su cónyuge de sexo femenino".

${ }^{35}$ Pese a caer en la ligereza del casuismo, parece evidente que las figuras tipificadas en Guatemala y Nicaragua, por ejemplo, son expresión bastante más fiel de la ideología y movimientos sociales que dieron pábulo a la noción de femicidio. De ahí que algunos critiquen al legislador chileno, pues, si su objetivo era crear una subespecie delictiva que estigmatizara la conducta, entre las posibles opciones, escogió la más 
GONZÁLEZ, Diego. "El delito de parricidio: consideraciones críticas sobre sus últimas reformas".

En términos de estructura típica, el femicidio abarca eventos que al socaire de la normativa trastocada ya constituían parricidio: quitar la vida a la cónyuge o a la conviviente. En cambio, sí revela una importantísima alteración, tras extender su cobertura a la muerte de quienes han sido cónyuges o convivientes del culpable. Con todo y esto, la mudanza no aparejó una variación en el marco penal aplicable al parricidio, ni tampoco fijó un castigo superior para lo que ahora constituye femicidio. Que conductas idénticas y ofensivas de un mismo bien se denominen distintamente sólo en función del sexo del paciente, expresa una visible aporía, más aun si la punición es la misma. Pero, pese a lo paradójico que resulte, esto último evitó que se engendrara otro defecto acaso más grave, a saber, que con pretexto de una supuesta discriminación positiva en favor de las mujeres, se agravara únicamente la muerte de éstas, pasando de contrabando una flagrante infracción al principio de igualdad.

Como se aprecia, la única diferencia sobre este apunto afecta a quien ultima a su ex cónyuge o ex conviviente, en tanto las penas del homicidio simple ceden paso a las harto más severas del artículo 390. Un ilustrativo modo de desnudar la real extensión típica que comportó esta reforma, resulta de su cotejo con las hipótesis que antes podían excluirse del parricidio, ora por ser discutidas, ora porque la propia ley no les permitía cabida. Dentro del primer conjunto están los homicidios cometidos entre cónyuges separados judicialmente, o en que el matrimonio tenía carácter putativo o anulable; aquí las soluciones doctrinarias y jurisprudenciales no gozaron de uniformidad. En el segundo grupo se ubican los homicidios perpetrados entre divorciados; personas cuyo matrimonio era inexistente o decretado nulo; o en que uno de los cónyuges habíase declarado muerto presunto. Generalmente en dichas circunstancias no se vaciló en aplicar el tipo básico ${ }^{37}$. Hoy en día, empero, los supuestos de ambos grupos pueden encuadrarse en el tipo "quien ha sido su cónyuge", o bien en la fórmula "quien ha sido su conviviente", como cláusula residual.

Actualmente en tramitación está el proyecto de ley que establece un nuevo código penal Boletín No 9.274-07 de marzo de 2014-, el cual conserva ciertos elementos de la normativa vigente en la materia, pero sugiere también otros cambios sensibles ${ }^{38}$. Por lo pronto, destaca

tímida. Cfr. CORN, Emanuele, 'Il 'femminicidio' come reato. Spunti per un dibattito italiano alla luce dell'esperienza cilena”, Diritto Penale Contemporaneo, p. 12, en: http://www.penalecontemporaneo.it/upload/1379085952CORN\%202013a.pdf [visitado el 08.11.2014]. Crítico igualmente al respecto, RIED, Nicolás, "Un delito propio. Análisis crítico de los fundamentos de la ley de femicidio", REJ, no 16 (2012), pp. 171-193, pp. 180 y ss.

${ }^{36}$ En todo caso, la solución es de incompatibilidad. Para que opere la circunstancia referida, el autor debe obrar motivado por el desprecio que en él despierta el sexo o la identidad de género del paciente, elementos ya estimados al tiempo de fijar el tipo de femicidio, que, precisamente, sólo se satisface si la víctima es mujer. 37 Sobre estas discusiones, véase ETCHEBERRY, Alfredo, Derecho penal: Parte especial, t. III, $3^{\mathrm{a}}$ ed., Santiago: Editorial Jurídica de Chile, 1997, pp. 71 y ss. Cfr. asimismo POLITOFF, Sergio; MATUS, Jean Pierre; RAMÍREZ, María Cecilia, Lecciones de Derecho penal chileno: Parte especial, $2^{\mathrm{a}}$ ed., Santiago: Editorial Jurídica de Chile, 2005, pp. 75-77; y BULLEMORE, Vivian; MACKINNON, John, Curso de Derecho penal, t. III, Santiago: LexisNexis, 2005, p. 26.

${ }^{38}$ Artículo 213. Femicidio. Será sancionado con prisión de 10 a 20 años el varón que matare a la mujer que sea o haya sido su cónyuge, conviviente o pareja, cuando el hecho se haya cometido en razón de esa relación o vínculo.

Artículo 214. Homicidio intrafamiliar. El que, abusando de la confianza o de la vulnerabilidad de la víctima, matare a su cónyuge o conviviente, a un pariente por consanguinidad o por afinidad en toda la línea recta o en la colateral hasta el tercer grado inclusive que viva bajo el mismo techo, o a una persona menor de 18 años, 
Polít. crim. Vol. 10, No 19 (Julio 2015), Art. 7, pp. 192-233.

[http://www.politicacriminal.cl/Vol_10/n_19/Vol10N19A7.pdf]

la supresión del parricidio, como la clara intención de otorgar autonomía al femicidio frente al sugerido delito de "homicidio intrafamiliar". Sobre este entendido, la figura del femicidio acusaría dos importantes alteraciones: la ampliación del círculo de sujetos pasivos a la mujer que sea o haya sido pareja del hechor -que ahora sí, efectivamente, debe ser un varón- y la exigencia expresa de que la muerte sea perpetrada en razón de la relación o vínculo existente entre ambos. Respecto de lo primero, el peligro que inmediatamente acecha es la indeterminación conceptual y la dificultad probatoria que consigo trae la expresión "pareja". Con relación al segundo punto, nos parece que, si la fórmula persigue exigir una determinada disposición subjetiva de parte del agente, no es la más idónea, por cuanto el desprecio que mueve a éste se deja sentir sobre la víctima, no en el vínculo que lo liga a ella. Como indicamos, se proyecta incluir también el llamado "homicidio intrafamiliar", en lo que aparenta combinar dos circunstancias agravantes genéricas con el contexto de violencia intrafamiliar definido en el artículo 5 de la Ley $\mathrm{N}^{\mathrm{o}} 20.066$. Estableciendo una pena proporcionada al reproche que merecen tales hechos, dicha figura está provista de mayor sentido que el actual parricidio.

Retomando la problemática configuración actual del parricidio en Chile, hemos podido confirmar, mediante la revisión de sus últimas reformas, que del empleo de una técnica legislativa poco prolija han surgido graves preocupaciones. Quizás hoy el interrogante más obvio sea éste: ¿no resulta preocupante que nuestro país siga ampliando un delito que hace décadas, y por buenas razones, se bate en retirada en el Derecho comparado? En lo sucesivo, sin embargo, cifraremos nuestra atención sólo en dos defectos que acusa el parricidio, cuyo punto en común es que ambos determinan su esfera de aplicación subjetiva. El primero lo constituye el empleo de la expresión conviviente, por cuanto suscita serios reparos interpretativos que la hacen pugnar con el mandato de determinación. La otra disfunción dice relación con la imposibilidad de compaginar el fundamento técnico de la agravación con la extensión típica que ahora abarca a las relaciones fenecidas. Después de abordar estos puntos, discurriremos brevemente sobre las desventajas de ofrecer al Derecho penal como única herramienta de solución para esta clase de conflictos.

\section{El concubinato como elemento normativo en el tipo de parricidio y su pugna con el principio de determinación.}

\subsection{Falta de regulación sistemática del concubinato en Chile.}

Sólo en el último trámite constitucional de la reforma que concluyó en la Ley № 20.066, se agregó al conviviente como eventual sujeto de parricidio. Su finalidad consistió en aplicar, respecto de los delitos contra la vida, la misma lógica seguida en el proyecto, ya que agravaba las lesiones cometidas en el contexto definido como violencia intrafamiliar ${ }^{39}$.

\footnotetext{
mayor de 70 años o discapacitada que se encuentre bajo el cuidado o dependencia propios o de cualquier integrante de la familia y que viva bajo el mismo techo, será sancionado con prisión de 10 a 20 años.

39 BIBLIOTECA NACIONAL DEL CONGRESO DE CHILE, Historia de la Ley $N^{o}$ 20.066, p. 470, en: http://www.leychile.cl/Navegar/scripts/obtienearchivo?id=recursoslegales/10221.3/561/1/HL20066.pdf [visitado el 07.11.2014].
} 
GONZÁLEZ, Diego. "El delito de parricidio: consideraciones críticas sobre sus últimas reformas".

Varios años después de la enmienda, todavía hoy es posible formular diferentes críticas. Partiendo por lo más básico, parece evidente que la misma expresión "conviviente" no es la más apropiada, pues, según su tenor literal, puede llevar al absurdo de incluir en el tipo, por ejemplo, a otros familiares o amigos que se han allegado en el hogar común ${ }^{40}$. Desde luego, con paladino desacierto, el legislador quiso aludir a los concubinarios, pese a que, para evitar términos peyorativos, pudo recurrir a locuciones más certeras, como han hecho otros $\operatorname{ordenamientos}^{41}$. La referencia, en definitiva, deberá entenderse dirigida a la convivencia more uxorio, más modernamente denominada unión de hecho. En cualquier caso, no es la imprecisión semántica el principal problema.

Antes de la introducción del conviviente, toda posible víctima de parricidio estaba definida en el Código civil, o se contaba a lo menos con preceptos que permitían dotar de contenido al elemento típico en cuestión. El sentido de las voces "padre", "madre", "ascendiente" y "descendiente", se puede asir del artículo 28. Lo propio sucede con los vocablos "hijo" y "cónyuge"; el primero definido expresamente en el artículo 33, y el segundo se extrae de los artículos 132 y siguientes, del mismo cuerpo legal. Luego, en cada uno de estos casos, se compagina el refuerzo de la sanción penal con un reconocimiento y una tutela civil previos de tales relaciones. Un panorama muy distinto presenta la situación del conviviente, dada la orfandad legislativa de que adolece en el ordenamiento jurídico chileno.

Durante el siglo XIX la legislación civil chilena guardó total mutismo sobre el concubinato, mientras que en sede penal sólo se vinculó de modo indirecto con una figura delictiva ${ }^{42}$. El escenario descrito se alteró levemente cuando, desde mediados de la centuria pasada, la voz comenzó a emplearse en ciertas leyes, aunque en forma aislada y para efectos muy diversos. Revisaremos parte de nuestra escasa normativa extrapenal al respecto ${ }^{43}$.

Una primera mención aparece en la Ley $\mathrm{N}^{\circ} 9.293$ de 1949, que hizo solidariamente responsable del pago de la obligación alimenticia a quien viviera en concubinato con el padre, madre o cónyuge del alimentario. Le siguió la Ley $\mathrm{N}^{\mathrm{o}} 10.271$ de 1952, que modificó el Código civil al establecer una presunción de paternidad respecto del hombre que mantuviere concubinato con la madre del alimentario. El decreto supremo 892 del Ministerio de Previsión Social de 1958 reconoció el derecho al pago de la cuota mortuoria a quien acreditase que había mantenido una convivencia habitual con la persona fallecida. Más tarde, la Ley No 17.564 de 1971, en materia de sismos o catástrofes, consideró como beneficiario de un subsidio al conviviente de la persona fallecida. La Ley $\mathrm{N}^{\mathrm{o}} 19.325$ de 1994 -antigua ley de violencia intrafamiliar-, ocupó la voz comentada al definir acto de violencia intrafamiliar. Luego, el Código procesal penal del año 2000, recurrió a la palabra

\footnotetext{
${ }^{40}$ Según el Diccionario de la Real Academia Española, conviviente es "cada una de las personas con quienes comúnmente se vive".

${ }^{41}$ Sirva de ejemplo el artículo 1 de la Ley No 54 de Colombia: "Hombre y mujer, que sin estar casados, hacen una comunidad de vida permanente y singular".

${ }^{42}$ El Código penal dio por ilícitas ciertas uniones no susceptibles de ser tenidas como concubinato. En concreto, por medio del antiguo delito de amancebamiento — derogado artículo 381—, el cual castigaba al marido que mantenía a la manceba dentro de la casa conyugal, o fuera de ella con escándalo.

${ }^{43}$ Para un examen más detenido y completo sobre este punto, véase BARRIENTOS, Javier, "Sobre la noción de 'conviviente' utilizada en el artículo 390 del Código penal”, Revista Chilena de Derecho Privado, $\mathrm{n}^{\circ} 7$ (2006), pp. 191-233, pp. 194 y ss.
} 
Polít. crim. Vol. 10, № 19 (Julio 2015), Art. 7, pp. 192-233.

[http://www.politicacriminal.cl/Vol_10/n_19/Vol10N19A7.pdf]

conviviente para enunciar las víctimas por asimilación y las personas que no están obligadas a declarar como testigos en el juicio oral. A su vez, la Ley No 19.968 de 2004, que creó los Tribunales de Familia, estableció el derecho del testigo a no contestar preguntas que puedan incriminar a su conviviente. En el año 2010, la Ley No 20.413, sobre la mal llamada donación de órganos, hizo reiteradas menciones a la figura del conviviente, con objeto de regular los posibles beneficiarios de la dación y las personas que pueden autorizarla. En materia urbanística, el decreto supremo 52 del Ministerio de Vivienda y Urbanismo de 2013, nombra al conviviente al fijar quiénes comprenden la familia nuclear.

Urge destacar que ninguno de estos cuerpos aportó una definición legal o, cuando menos, los elementos que debe reunir una relación de hecho para ser calificada jurídicamente de concubinato $^{44}$. Lo anterior parece del todo lógico; no escapa aun al menos observador, que las leyes referidas sólo otorgan efectos concretos a estas uniones. Con todo, la voluntad del legislador chileno no ha sido la de proteger decididamente al concubinato como relación de familia. Prueba de ello es su actitud silente en materias de mayor interés. Así, entre tantas: los deberes que rigen las relaciones personales entre concubinarios; los derechos sucesorios de éstos; los efectos patrimoniales derivados del cese de la unión; o la legitimación activa en causas de indemnización de perjuicios en que fallece el compañero.

Por primera vez, en el año 2003, se presentó una iniciativa parlamentaria al respecto, mediante el "Proyecto de Ley de fomento de la no discriminación y contrato de unión civil entre personas del mismo sexo", Boletín No 3283-18, hoy archivado. Luego de una intensa discusión que se remonta al año 2010, mejor suerte parece haber corrido el proyecto "Acuerdo de vida en pareja y de los convivientes civiles", correspondiente a los Boletines $\mathrm{N}^{\mathrm{o}}$ 7011-07 y No 7873-07, refundidos, recientemente aprobado por el Congreso. En procura de guardar sistematicidad en el análisis de dos situaciones muy dispares, reservaremos para más adelante los comentarios sobre este proyecto que aún espera su publicación.

De toda forma, a despecho de esta laguna normativa que le antecedía, es notorio que en poco más de una década diversos tipos del catálogo de la Parte especial ampliaron su ámbito subjetivo de aplicación, sin esperar reforma legal alguna en tal sentido ${ }^{45}$. El criterio asistemático, por no decir antojadizo, que siguió el legislador, se revela luego de constatar que el "conviviente" no fue sin embargo añadido en los preceptos relativos a la legítima

\footnotetext{
${ }^{44}$ Cfr. BARRIENTOS, Javier, De las uniones de hecho: legislación, doctrina y jurisprudencia, Santiago: LexisNexis, 2008, pp. 24-25. Por este motivo, también, otros sitúan a la legislación chilena dentro de aquellas que mantienen una posición "abstencionista" con respecto al concubinato. Así, RAMOS PAZOS, René, Derecho de familia, t. II, $7^{\text {a }}$ ed., Santiago: Editorial Jurídica de Chile, 2010, p. 646.

${ }^{45}$ La primera al respecto fue la Ley $\mathrm{N}^{\circ} 19.617$ de 1999, que agregó un inciso segundo al artículo 259 del Código punitivo, conforme al cual se agrava la pena si la persona solicitada es, entre otras, conviviente de quien estuviere bajo la guarda del solicitante. Además, modificó el artículo 369, estableciendo reglas especiales para los delitos de violación o abuso sexual perpetrados por el cónyuge o conviviente en contra de aquél con quien hace vida común. En el año 2004, la Ley 19.927 modificó el derogado artículo 367 bis, instituyendo un tratamiento especial en la trata de personas cuando el autor era, entre varios, el conviviente de la víctima. La ya analizada Ley $\mathrm{N}^{\circ} 20.066$ de 2005, lo incorporó como sujeto pasivo de parricidio, aunque también lo hizo en la atenuante contemplada en la circunstancia $4^{a}$ del artículo 11. Finalmente, la Ley $\mathrm{N}^{\mathrm{o}}$ 20.480 de 2010, como se indicó antes, incluyó a quien ha sido conviviente del hechor como paciente de los delitos de parricidio y femicidio.
} 
GONZÁLEZ, Diego. "El delito de parricidio: consideraciones críticas sobre sus últimas reformas".

defensa de parientes, la circunstancia mixta de parentesco, el encubrimiento de cercanos, el abandono de personas desvalidas, ni la excusa legal absolutoria del artículo 489.

No son inconvenientes de puro orden práctico los que invitan a rechazar esta forma precipitada de legislar, sino también serios juicios de fondo. En efecto, presentar un Derecho penal divorciado en sus contenidos respecto de las ramas constitutivas, significa preterir la naturaleza garantizadora que reviste el primero ${ }^{46}$. Un ejercicio racional del ius puniendi se sujeta a la irrenunciable condición de que por medio suyo sólo se castigue la lesión de objetos previamente afirmados. De la creación y protección de los bienes jurídicos se ocupan otras tutelas, más específicas, eficaces y complejas, impulsadas por un sentido distinto de urgencia. Esta pauta fue la seguida por los ordenamientos que antes de incluir al concubinario como paciente de parricidio o de sus respectivos tipos de violencia doméstica, ya disponían de una regulación civil para las uniones de hecho ${ }^{47}$.

\subsection{La figura del conviviente y el debate en torno a sus elementos constitutivos.}

A raíz de la carencia de un estatuto legal, civilistas y penalistas han debido engolfarse en la difícil labor de fijar los caracteres identificadores del concubinato. Por existir ciertos rasgos y fines comunes con el matrimonio, una primera opción ha sido asimilarlo a su institución familiar más próxima, siendo éste el criterio al cual recurre con mayor asiduidad nuestra jurisprudencia ${ }^{48}$. Dicha idea, sin embargo, pasa por alto que, si lo esencial del concubinato es el designio de sus miembros en orden a llevar una vida en común, en el matrimonio este dato es perfectamente prescindible, comoquiera que su conservación depende de elementos jurídicos, no fácticos, y por ello guarda vigor incluso contra la voluntad de los cónyuges ${ }^{49}$.

Aun así, determinar los caracteres propios de esta figura, con escasa colaboración de la ley, tampoco es faena sencilla. Las aristas de este problema se acentúan con la falta de consenso teórico y la propuesta de ciertos requisitos que no siempre parecen justificarse. Tal sucede con el supuesto contenido sexual que debe revestir la unión y la ausencia de impedimentos matrimoniales $^{50}$. Ambos aspectos pueden discutirse. La índole sexual de la unión

\footnotetext{
${ }^{46}$ Sobre la índole sancionadora de esta rama jurídica, véase ZAFFARONI, Eugenio; ALAGIA, Alejandro; SLOKAR, Alejandro, Manual de Derecho penal: Parte general, $2^{\mathrm{a}}$ ed., Buenos Aires: Ediar, 2006, pp. 82, 371 y 372; y las anotaciones de GUZMÁN DALBORA, José Luis, "Sobre el significado íntimo y valor actual de la teoría del bien jurídico en la obra de Johann Birnbaum”, en: DEL MISMO, Figuras y pensamientos del Derecho penal contemporáneo, Montevideo-Buenos Aires: B de F, 2014, pp. 1-29, pp. 19 y 20.

${ }^{47}$ En España existe una normativa estatal, y en algunos casos autonómica, que data de los años ochenta. Suecia reguló el concubinato mediante la Ley № 232 de 1987 sobre "El hogar común de cohabitantes extramatrimoniales". Suiza, a partir de 2004, trata en su Código civil las denominadas "uniones de hecho registradas". En Sudamérica, por ejemplo, Bolivia reconoció el concubinato en su Código de familia de 1977; Brasil hizo lo propio en su nuevo Código civil de 2002; y en el Perú, el Código civil las define en su artículo 326. Por fin, Costa Rica y Guatemala también cuentan con un tratamiento civil de la materia; el Código de familia costarricense regula latamente el concubinato a partir del Título VII, mientras el Código civil guatemalteco se hace cargo de él en los artículos 173 y siguientes.

${ }^{48}$ Así, la Sentencia de la Corte Suprema (en adelante, "SCS”) de 2 de septiembre de 2014, Rol No $1978 / 2014$.

${ }^{49}$ Cfr. HERNÁNDEZ BASUALTO, Héctor, "La definición de 'convivencia' en el art. 390 del Código penal", Informes en Derecho. Doctrina procesal penal 2010, nº 8 (octubre, 2011), pp. 47-52, p. 49.

${ }^{50}$ En favor de ambas condiciones se pronuncia BARRIENTOS, De las uniones de hecho, cit. nota $\mathrm{n}^{\circ} 44$, pp. 28-32 y 46-47. Partidarios sólo de la necesidad de su contenido sexual, DONOSO, Florencia; RIOSECO, Andrés, El concubinato ante la jurisprudencia chilena, Santiago: LexisNexis, 2007, p. 18. En cambio, en
} 
Polít. crim. Vol. 10, № 19 (Julio 2015), Art. 7, pp. 192-233.

[http://www.politicacriminal.cl/Vol_10/n_19/Vol10N19A7.pdf]

descartaría a las parejas cuyos miembros son ancianos, padecen de alguna impotencia, o sencillamente se han resuelto por la abstinencia. Mientras la pretendida aptitud matrimonial de los concubinarios, daría la espalda a la realidad, excluyendo parejas que se han formado precisamente porque sus integrantes no quieren o no pueden casarse. Por otra parte, los requerimientos de publicidad y afecto, concebidos para excluir uniones furtivas o de naturaleza patrimonial, tampoco se aceptan unánimemente ${ }^{51}$. Incluso el requisito más obvio, esto es, hacer vida en común, también provoca algunas dificultades; de un lado, la incertidumbre sobre los grados de seriedad y permanencia exigibles a la relación ${ }^{52}$, y, de otro, cierta interpretación amplia sostenida por el Ministerio Público ${ }^{53}$.

No podrá negarse, sin embargo, que el punto neurálgico de la polémica está constituido por el supuesto carácter heterosexual de las uniones de hecho ${ }^{54}$. Esta idea, lógica consecuencia de la extrapolación de requisitos matrimoniales, lleva a que algunos nieguen la posibilidad de parricidio en muertes ocurridas entre concubinarios del mismo sexo. Garrido Montt, uno de los penalistas nacionales que se pronuncia en favor de esta tesis, ofreció, además de una consideración histórica, tres argumentos en su respaldo. En primer lugar, señaló que las expresiones conviviente y cónyuge están unidas por la preposición "o", por lo cual existe un claro sentido de homologación. Además -decía el profesor-, el artículo 5 de la Ley N $^{\circ}$ 20.066, a diferencia del Código penal, emplea la fórmula "relación de convivencia", precisamente para comprender otro tipo de uniones de familia. Por último, concluyó que entenderla referida a otra clase de vinculación sentimental, importaría aplicar una interpretación analógica en perjuicio del culpable $\mathrm{e}^{55}$.

No compartimos dicha opinión. Si bien la preposición señalada puede denotar equivalencia en ciertos contextos, su primera acepción ordena interpretarla como indicación de separación o diferencia, lo que convierte a la frase "cónyuge o conviviente" en un juicio disyuntivo. En seguida, la opción de manejar nociones diferenciadas de concubinato, en

contra de esta última exigencia, LÓPEZ DÍAZ, Carlos, Manual de Derecho de familia y tribunales de familia, t. I, Santiago: Librotecnia, 2005, p. 88.

${ }^{51}$ En favor de ellas, véase BARRIENTOS, De las uniones de hecho, cit. nota $\mathrm{n}^{\circ}$ 44, pp. 44-46. En contra, véase RAMOS PAZOS, Derecho de familia, cit. nota $\mathrm{n}^{\circ} 44, \mathrm{p}$. 650. Sobre las vacilaciones de la jurisprudencia en este punto, véase VARGAS, Rafael, Derecho de familia, t. III, Santiago: Metropolitana, 2010, pp. 293 y ss. La exigencia de afecto, si bien tiene el mérito de excluir a las relaciones de mera amistad, no deja de ser problemática, justamente para casos de parricidio o violencia intrafamiliar, en los que tal apego no existe o ya se perdió.

${ }^{52}$ Esto, a su turno, repercute en dudas respecto de la edad mínima que han debido alcanzar los concubinarios y el tiempo básico de duración de la convivencia.

${ }^{53}$ Según el Oficio N ${ }^{\circ} 111 / 2010$, emitido por la Fiscalía Nacional, la convivencia es una cuestión de hecho, que supone, entre otros elementos, "la cohabitación de los sujetos, aunque esto no implique vivir necesariamente bajo un mismo techo, si las circunstancias económicas no lo permiten”. Disponible en: http://www.fiscaliadechile.cl/Fiscalia/archivo?id=587\&pid=50\&tid=1 [visitado el 03.11.2014].

${ }^{54}$ Opinión que siguen los civilistas. Cfr. BARRIENTOS, De las uniones de hecho, cit. nota $\mathrm{n}^{\circ}$ 44, p. 29; RAMOS PAZOS, Derecho de familia, cit. nota n 44, p. 648; LÓPEZ, Manual de Derecho de familia, cit. nota $\mathrm{n}^{\circ} 50$, p. 87.

55 GARRIDO MONTT, Mario, Derecho penal: Parte especial, t. III, 4 a ed., Santiago: Editorial Jurídica de Chile, 2010, pp. 77 y 78. Cfr. también SALINERO, Sebastián, "El femicidio. Una revisión crítica", Microjuris, 16 de marzo de 2011, p. 14 [visitado el 10.11.2014], en cuyo sentir, a partir de una interpretación teleológica de la norma y de la historia fidedigna de la ley, se desprende que la protección es alusiva únicamente a las uniones de hecho entre hombres y mujeres. 
GONZÁLEZ, Diego. "El delito de parricidio: consideraciones críticas sobre sus últimas reformas".

función del delito que se perpetra, parece injustificada ${ }^{56}$, riñe con la coherencia interna del sistema y distorsiona más un concepto ya indeterminado. No hemos de apresurarnos a pensar que la imputación a título de parricidio encierra para estos casos una analogía in malam partem; puesto que las uniones heterosexuales tampoco tienen un régimen legal, falta el presupuesto básico a todo razonamiento analógico. En fin, el incumplimiento de deberes personales de protección, respeto y socorro entre compañeros, se verifica con absoluta indiferencia de su sexo, por lo que, visto desde el fundamento de la agravación, no hay razón alguna para desempatarlas. Dicho todo lo cual, pese a que la mayoría de los penalistas chilenos incluyen las relaciones homosexuales dentro de la noción de conviviente $^{57}$, la praxis judicial ha sido pendular en este sentido ${ }^{58}$.

El olvido legislativo que ensombrece el escenario, aliado en gran suma a las desavenencias que provoca en la doctrina y jurisprudencia, sirve de pábulo a otros contratiempos, esta vez de corte probatorio, pero asimismo espinosos. Efectivamente, existe en el concubinato un importante factor subjetivo: la voluntad permanente de convivir. Tal elemento está lejos de reducirse a la circunstancia de hacer vida bajo un mismo techo, y por semejante motivo su prueba no se logra mecánicamente por signos externos ${ }^{59}$. Dicha dificultad argumentativa se deja sentir en el ámbito de la violencia intrafamiliar, donde el Ministerio Público, muchas veces, ante la imposibilidad de comprobar este factor interno, se ve forzado a acreditar la relación de contexto sobre la existencia de hijos comunes entre los compañeros, si los hay.

Para culminar, a este variado conjunto de problemas, se adosa otro no menos grave en materia de recursos. Según el criterio general que siguen los tribunales superiores, la calificación del concubinato constituye una cuestión de hecho ${ }^{60}$, de guisa que el recurso de nulidad es improcedente, salvo por infracción a las reglas de valoración de la prueba.

Habiendo revisado la confusa situación del concubinato en Chile, toca ahora decidir su caracterización como elemento típico del parricidio y la categoría específica a la que responde en cuanto tal. Solamente después de ello podremos juzgar la relación de armonía o contradicción que guarda esta cláusula con el principio de legalidad.

\footnotetext{
${ }^{56}$ Por ahora, el concubinato es un elemento normativo cultural. Sería malsano restringir arbitrariamente su noción en una sociedad pluralista, donde diversas culturas y éticas pueden legítimamente confrontarse y convivir. Cfr. PULITANÒ, Domenico, Diritto Penale, Terza edizione, Torino: Giappichelli, 2009, p. 174.

${ }^{57}$ Así, a propósito del parricidio, MATUS/RAMÍREZ, Lecciones de Derecho penal: Parte especial, cit. nota n 33, p. 68; y también BALMACEDA HOYOS, Gustavo, Manual de Derecho penal: Parte especial, Santiago: Librotecnia, 2014, p. 45. Para efectos de violencia intrafamiliar, VILLEGAS, Myrna, "El delito de maltrato habitual en la Ley No 20.066 a la luz del derecho comparado", Política Criminal, vol. $7, \mathrm{n}^{\circ} 14$ (diciembre, 2012), pp. 276-317, p. 307, en: http://www.politicacriminal.cl/Vol_07/n_14/Vol7N14A2.pdf [visitado el 28.10.2014]. Y respecto de la excusa legal absolutoria del artículo 369, RODRÍGUEZ COLLAO, Luis, Delitos sexuales, Santiago: Editorial Jurídica de Chile, 2004, p. 296.

${ }^{58}$ Así, requiriendo la diferencia de sexo, véase, por ejemplo, la SCS, de 7 de marzo de 2012, Rol No $337 / 2011$ y la SCS, de 24 de junio de 2013, Rol No 5367/2012. En cambio, sólo excepcionalmente se ha reconocido el concubinato homosexual. En este sentido, paradigmática, la Sentencia de la Corte de Apelaciones (en adelante, "SCA") de La Serena, de 8 de enero de 2007, Rol No 373/2006.

${ }^{59}$ Cfr. HERNÁNDEZ BASUALTO, "La definición de 'convivencia", , cit. nota n ${ }^{\circ}$ 49, p. 50.

${ }^{60}$ Así, la SCA de Temuco, de 3 de julio de 2012, Rol № 427/2012; y recientemente la SCA de Valparaíso, de 13 de mayo de 2014, Rol No 510/2014.
} 
Polít. crim. Vol. 10, № 19 (Julio 2015), Art. 7, pp. 192-233.

[http://www.politicacriminal.cl/Vol_10/n_19/Vol10N19A7.pdf]

\subsection{El elemento normativo del conviviente y su compleja relación con el principio de determinación. Comentario a una sentencia del Tribunal Constitucional chileno.}

En los terrenos de la tipicidad, desde principios del siglo pasado suele imponerse, aunque no sin ciertos matices, una división entre elementos meramente descriptivos y elementos normativos. Tradicionalmente, se ha entendido que los primeros aluden a objetos que, por existir u ocurrir en el mundo de las cosas, son aprehensibles mediante un procedimiento cognoscitivo puro; los segundos, a la inversa, designan ideas cuya concreción al caso exige efectuar una valoración previa, sea jurídica o cultural ${ }^{61}$. Con todo, tan pronto surgía la doctrina hubo quienes vaticinaron su carácter efímero, dado el íntimo enlace estructural que presenta esta pareja de conceptos ${ }^{62}$. En desmedro de la existencia de reales elementos descriptivos, dicha crítica, que hasta hoy se atribuye a Wolf, llegó al extremo de concebir únicamente elementos normativos, pues aquéllos recién adquirirían importancia jurídica cuando forman parte del supuesto de una norma ${ }^{63}$. Pese a lo indicado, y aun de aceptarse que el contraste entre tales categorías se funda exclusivamente en una cuestión gradual, debido a su inevitable mixtura, damos razón a la doctrina que rescata cierta funcionalidad en la vieja distinción de matriz alemana, aunque siga en entredicho su utilidad dogmática ${ }^{64}$. En efecto, dado que existen elementos típicos, cuyas propiedades anejas pueden suscitar problemas de legalidad con especial facilidad, se puede salvar de esta oposición conceptual al menos un rendimiento político-criminal ${ }^{65}$. Desde ya anticipamos que los conceptos extrajurídicos -máxime si son culturales-, dificultan sobremanera el cumplimiento del mandato de determinación, faz material de aquél principio cardinal. La noción de conviviente del artículo 390 se identifica justamente con esta clase de elementos.

\footnotetext{
${ }^{61}$ El criterio clásico de distinción es de carácter valorativo. Véase un ejemplo de su empleo en los conceptos proporcionados por JESCHECK, Hans-Heinrich; WEIGEND, Thomas, Tratado de Derecho penal: Parte general, Trad. de la 5 a ed. alemana: OLMEDO, M., Granada: Comares, 2002, pp. 138-139. En cambio, KINDHÄUSER, Urs, "Hechos brutos y elementos normativos del tipo", Trad.: DE LA VEGA, O., InDret, $\mathrm{n}^{\circ}$ 2 (2014), pp. 15-16, crítico de este parámetro, sostuvo que los elementos normativos no siempre envuelven valoraciones, sino sólo cuando se usan para comparar o graduar, pudiendo cumplir otras funciones.

Según los criterios normativos - cuya aceptación es más reciente-, lo que permite distinguir a ambos elementos es la referencia a normas jurídicas o culturales, como presupuesto lógico para su entendimiento. Véase en dicho sentido, PULITANÒ, Diritto Penale, cit. nota n ${ }^{\circ}$ 56, pp. 172-173.

${ }^{62}$ Cfr. GRÜNHUT, Max, "Formación de conceptos y aplicación del Derecho en el Derecho penal", Anuario de Filosofía jurídica y social, Trad.: GUZMÁN DALBORA, José Luis, no 22 (2004), pp. 307-329, p. 323, quien así lo advirtió, aunque, acto seguido, defendió la distinción, señalando que entre ambos conceptos existe igualmente una diferencia de estructura lógica, que en sus efectos psíquicos repercute en el juez.

${ }^{63}$ En tanto que ningún elemento sería estrictamente normativo, ya que la mayoría de ellos también contienen referencias a sustratos fácticos. Cfr. ROXIN, Claus, Derecho penal: Parte general, Trad. de la $2^{\mathrm{a}}$ ed. alemana: LUZÓN PEÑA, Diego-Manuel, Madrid: Civitas, 1997, p. 307. Sobre éste y otros reparos a la clasificación, véase también, SUAY HERNÁNDEZ, Celia, "Los elementos normativos y el error”, ADPCP, t. XLIV, fasc. I (1991), pp. 97-142, pp. 102 y ss.

${ }^{64}$ Últimamente se relativiza la relevancia que en principio tendría esta diferencia para delimitar el contenido del dolo y los efectos del error que recae sobre estos elementos. Véase VAN WEEZEL, Alex, La garantía de Tipicidad en la Jurisprudencia del Tribunal Constitucional, Santiago: LegalPublishing, 2011, pp. 88 y ss.

${ }^{65}$ Así también OSSANDÓN, María Magdalena, La formulación de tipos penales: Valoración crítica de los Instrumentos de Técnica Legislativa, Santiago: Editorial Jurídica de Chile, 2009, pp. 109 y 122, quien piensa que puede aceptarse un criterio normativo para la distinción, pero no desde un punto de vista cualitativo, y en todo caso limitando su utilidad político-criminal a la subcategoría de elementos normativos extrajurídicos.
} 
GONZÁLEZ, Diego. "El delito de parricidio: consideraciones críticas sobre sus últimas reformas".

Para considerar una relación de concubinato como tal, primero debe discernirse sobre la concurrencia de requisitos especiales. No refiere sólo a una base exclusivamente fáctica o natural, aunque es bien noto que supone un sustrato empírico. En su caso, como dijimos, el tenor literal no agota el contenido del concepto, al tiempo que la experiencia cotidiana tampoco traza por sí misma y de manera clara sus contornos. Se trata, entonces, de un elemento típico normativo, por cuanto su verificación precisa de un juicio de valor, de un ejercicio de comprensión intelectual o, con mayor rigor, del presupuesto lógico de otra norma -jurídica o cultural-, que lo dote de sentido. Las características y la naturaleza propia de esta institución aconsejan que su definición sea aportada directamente por la ley, tal cual hace con el matrimonio. No obstante, mientras ninguna norma penal o extrapenal acometa a su objeto con la debida propiedad, nos será prohibido calificar la relación de concubinato como elemento normativo jurídico. De ahí que, por confiar al juez una valuación que va más allá de las posibilidades mentales que la legalidad vigente le permite representarse, entendamos que la referencia al conviviente constituye un elemento normativo de índole empírico-cultural ${ }^{66}$, es decir, un páramo erizado de dudas.

Los motivos para censurar el recurso a estos juicios normativos son varios, aunque, en el fondo, cada uno será expresión de un conflicto de tipicidad subyacente. Así pues, a la indeterminación de tales fórmulas, inmediatamente se asocia un obstáculo para la certeza subjetiva que ha de proyectar toda norma penal, en tanto presupuesto de previsibilidad en la aplicación del Derecho ${ }^{67}$. De otra parte, su inmanente vaporosidad introduce el peligro permanente de tornar elástico el tipo delictivo, hasta el punto de concluir en integraciones analógicas ${ }^{68}$. A lo dicho debe añadirse otro riesgo latente: que la sujeción a la ley, en los casos más extremos, se termine disipando en favor de una determinada convicción interna del juez, por no encontrar en aquélla las referencias normativas que le habrían permitido resolver el caso, y carecer de la posibilidad de excusarse del fallo ${ }^{69}$. Y, en fin, su empleo indiscriminado va en claro perjuicio del principio de objetividad, desde que la falta de precisión en los tipos necesariamente entorpece su aplicación uniforme ${ }^{70}$.

\footnotetext{
${ }^{66}$ De este modo acuñados por JIMÉNEZ DE ASÚA, Luis, Tratado de Derecho penal, t. III, $4^{\mathrm{a}}$ ed., Buenos Aires: Losada, 1963, pp. 900-905. Con otra terminología, véase una exposición y crítica del empleo de los referidos elementos en ZAFFARONI, Eugenio, Tratado de Derecho penal: Parte general, $t$. III, Buenos Aires: Ediar, 1981, pp. 284-287. Cfr., asimismo, PULITANÒ, Diritto Penale, cit. nota nº 56, pp. 174-175.

${ }^{67}$ Así, PALAZZO, Francesco, Corso di Diritto Penale: Parte generale, Terza edizione, Torino: Giappichelli, 2008, p. 139, quien ve en la tríada: determinación-certeza-cognoscibilidad, una condición de funcionamiento de la ley penal. En contra, SILVA SÁNCHEZ, Jesús-María, Aproximación al Derecho penal contemporáneo, $2^{\mathrm{a}}$ ed., Montevideo-Buenos Aires: B de F, 2010, p. 408, dado que "los mecanismos que ponen en contacto al ciudadano con las normas son indirectos". Con todo, agreguemos que, precisamente porque la ley penal habla al juez, y que éste, al fijar el ámbito de lo prohibido en el caso concreto, obra como mediador, es que se hace necesaria su claridad; de otro modo el Poder judicial no podría transmitir seguridad alguna a los justiciables.

${ }^{68}$ Esto es consecuencia de la estrecha relación existente entre los principios de determinación y taxatividad. Cfr. MANTOVANI, Ferrando, Diritto Penale: Parte generale, Sesta edizione, Padova: Cedam, 2009, p. 60.

${ }^{69}$ Hay quienes aprecian además un atropello al principio democrático, ya que sería el juez, órgano carente de legitimación democrática directa, el que demarcaría el contenido del precepto. En este sentido, SILVA SÁNCHEZ, Aproximación, cit. nota n ${ }^{\circ}$ 67, p. 409 y VAN WEEZEL, La garantía de Tipicidad, cit. nota $\mathrm{n}^{\circ}$ 64, p. 15.

${ }^{70}$ Cfr. PALAZZO, Corso di Diritto penale, cit. nota no 67, p. 140. Así también OSSANDÓN, La formulación de los tipos penales, cit. nota ${ }^{\circ}$ 65, p. 534.
} 
Polít. crim. Vol. 10, № 19 (Julio 2015), Art. 7, pp. 192-233.

[http://www.politicacriminal.cl/Vol_10/n_19/Vol10N19A7.pdf]

Pocos autores nacionales se han ocupado del concepto de conviviente y su problemática relación con el principio de legalidad. Generalmente priman las críticas, pero no hasta el extremo de acusar su inconstitucionalidad ${ }^{71}$. Aun así, resultaba ineluctable que en algún momento el Tribunal Constitucional chileno se pronunciara sobre la materia, de cara a una eventual transgresión al artículo $19 \mathrm{~N}^{\circ} 3$ inciso final de la Carta Fundamental. Esto recién ocurrió con la sentencia Rol N $N^{\circ} 1.432 / 09$, de 5 de agosto de 2010, oportunidad en que el Tribunal conoció de un requerimiento de inaplicabilidad del artículo 390 del Código penal -junto con otros preceptos del Código procesal penal-, en la causa RIT N ${ }^{\circ}$ 22-2009, pendiente para ese entonces ante el Tribunal de Juicio Oral en lo Penal de Los Andes.

Interesa de dicho fallo el capítulo tercero, relativo a la tipicidad penal. En sus primeras reflexiones, los sentenciadores discurren sobre el contenido del principio y su consagración constitucional. En seguida, atribuyen al concepto de conviviente el carácter de elemento normativo, dedicando largos pasajes a destacar las diferencias que separan a tal clase de elementos típicos de las denominadas leyes penales en blanco ${ }^{72}$, aclaración que se debe a una confusión de términos en que incurrió el recurrente. Esta circunstancia, sin embargo, parece haber desviado el problema, ya que se echa en falta un examen más detenido sobre las subcategorías de elementos normativos, crucial para estos efectos.

Los argumentos esgrimidos por el Tribunal Constitucional para negar una infracción al principio de legalidad pueden reducirse básicamente a cuatro. Primero, aludió a la historia fidedigna del precepto impugnado, en la cual, según los sentenciadores, ya se adelantaba que su significado debía ser definido por el juez del fondo. A continuación, se indicó que el concepto de convivencia podía circunscribirse en virtud de su relación con el matrimonio. En tercer lugar, se mencionó una plétora de cuerpos legales en que se cita al conviviente, razón por la cual no sería una noción ajena a nuestro Derecho. En fin, el capítulo se cerró anotando que existe una interpretación judicial y doctrinaria muy sólida de su significado ${ }^{73}$.

A pesar de que el requerimiento se rechazó también por conferirse carácter inamovible a los hechos fijados por los jueces de la instancia, creemos que los fundamentos aducidos por el Tribunal Constitucional no resuelven un problema que, de no mediar regulación legal, es de difícil despacho. Ya hemos subrayado lo discutible que es la opción de confiar a la

\footnotetext{
71 Así, HERNÁNDEZ BASUALTO, "La definición de 'convivencia”, cit. nota n ${ }^{\circ} 49$, p. 48, reprocha lo "extraordinariamente imprecisos que son sus contornos, toda vez que se aparta de la segura regla general de formalización institucional de las uniones personales en nuestro ordenamiento, que es el matrimonio, para extenderse a uniones de base exclusivamente fáctica". Por su lado, MEDINA JARA, Rodrigo, Manual de Derecho penal: Parte especial, Santiago: LexisNexis, 2007, p. 66, expresa que "su aparición en el parricidio, sin haber definido los alcances de lo que el ordenamiento nacional debe entender por convivencia, es profundamente distorsionador". En la misma línea, SALINERO, "El femicidio", cit. nota n 55, p. 14, quien piensa que el concepto de conviviente, pese al común y cultural conocimiento que nuestra sociedad entiende por tal, "es impreciso desde el punto de vista gramatical y riesgoso en el mandato de certeza". De modo más explícito, BARRIENTOS, "Sobre la noción de "conviviente", cit. nota $n^{\circ} 43$, pp. 230-231, indica que esta fórmula "puede dar pie para sostener que en dicha parte el artículo 390 del Código penal se encontraría herido de inconstitucionalidad por una eventual vulneración a la garantía de determinación típica".

${ }^{72}$ Véanse los fundamentos jurídicos $29^{\circ}$ a $34^{\circ}$.

${ }^{73}$ Véanse los fundamentos jurídicos $35^{\circ}, 36^{\circ}, 37^{\circ}$ y $38^{\circ}$, respectivamente.
} 
GONZÁLEZ, Diego. "El delito de parricidio: consideraciones críticas sobre sus últimas reformas".

discrecionalidad del juzgador la precisión de un elemento típico ${ }^{74}$. así como la idea de extrapolar sin más requisitos pensados para instituciones de naturaleza muy diversa. Respecto del limitado auxilio interpretativo que brinda la legislación y de las incógnitas académicas que aún despierta la materia, también nos remitimos a lo indicado supra.

El fallo comentado podrá ser merecedor de aceptación o censura. Mas nada de esto alterará lo excepcional que es la declaración de inconstitucionalidad por atropello al mandato de determinación. Esta pasividad en el control de las leyes punitivas, ampliamente criticada en otros países también, encuentra explicación en varios factores. Primero, implícitamente, aparecen imbricados aspectos de orden político, ya no sólo porque en sí misma "la anulación de una ley tiene un evidente coste democrático"75, sino además por la colisión de este postulado garantista con otras funciones o intereses a los que la vox populi asigna incluso mayor valor. Asimismo, la falta de consenso en cuanto a la significación y al alcance de esta manifestación de la legalidad es un importante obstáculo para su rigurosa aplicación $^{76}$. Sin embargo de lo dicho, es probable que las principales dificultades en el manejo de esta máxima provengan de su naturaleza gradual. Esto significa aceptar que ninguna norma podrá satisfacer niveles de certeza absoluta, ya que el lenguaje es una manifestación imperfecta del pensamiento; del mismo modo que, por mal formulada que esté, tampoco sería posible admitir la entera imprecisión de una norma, "a no ser que se trate de expresiones de pura fantasía o de locura"77. En este orden de ideas, para invalidar un precepto penal por indeterminado, prácticamente hace falta estar ante casos de grotesca vaguedad o francamente irracionales ${ }^{78}$. Aunque, en general, convendría preguntarse si acaso no asisten razones suficientes para desplegar un control estricto, siquiera cuando el castigo amenazado es particularmente severo, cual es el caso del parricidio en Chile ${ }^{79}$.

\footnotetext{
${ }^{74}$ Respecto de una respuesta semejante ofrecida por el Tribunal Constitucional español, cabe recordar la crítica formulada por Bacigalupo, en el sentido de que "toda cláusula general puede ser aplicada mediante un proceso de concreción, pero ello no garantiza la concreción previa al hecho, que es de la esencia del principio de legalidad". BACIGALUPO, Enrique, Principios de Derecho penal, 4ª ed., Madrid: Akal, 1997, p. 76.

${ }^{75}$ LAZCURAÍN, Juan Antonio, "El control constitucional de las leyes penales", en: VELÁSQUEZ, Fernando; VARGAS, Renato (Compiladores), Derecho penal y Constitución, Bogotá: Universidad Sergio Arboleda, 2014, pp. 11-44, p. 18. En general, el autor critica el paralelismo de los tribunales constitucionales, al presentarse firmes en la proclamación del principio, pero en extremo deferentes a la hora de aplicarlo.

${ }^{76}$ Cfr. ROXIN, Claus, "El principio de determinación de la ley en el Derecho penal alemán", en: VAN WEEZEL, Alex (Ed.), Humanizar y renovar el Derecho penal: estudios en memoria de Enrique Cury, Santiago: LegalPublishing, 2013, pp. 109-141, p. 133. Aunque, en general, la relación entre los principios limitativos del ius puniendi y su reconocimiento constitucional, tampoco cuenta con una Dogmática general. Cfr. FERNÁNDEZ CRUZ, José Ángel, "Principalismo, garantismo, reglas y derrotabilidad en el control de constitucionalidad de las leyes penales", Revista de Ciencias Penales, vol. XLI, nº 3 (2014), pp. 91-114, p. 94.

${ }^{77}$ Cfr. PALAZZO, Francesco, "La legalidad y la determinación de la ley penal: el significado lingüístico, la interpretación y el concepto de la regla iuris", Revista Penal, Trad.: MELERO, Irene; BARÓN, Susana, no 25 (2010), pp. 104-116, p. 108.

${ }^{78}$ No obstante, para algunos, este principio sólo sería incompatible con los tipos vagos o absolutamente indeterminados, no así con los tipos elásticos, que comprenden una zona gris intermedia, con iguales sectores de certeza positiva y negativa. Así, MANTOVANI, Diritto penale, cit. nota $\mathrm{n}^{\circ} 68$, pp. 66-67. Para otros, la elasticidad en los tipos es suficiente para engendrar problemas de legalidad. Cfr. FIANDACA, Giovanni; MUSCO, Enzo, Diritto penale: Parte generale, Quinta edizione, Bologna: Zanichelli, 2007, p. 83.

${ }^{79}$ Sobre la estrecha relación entre el principio de determinación y la cuantía de la sanción penal, véase LAZCURAÍN, "El control constitucional", cit. nota n ${ }^{\circ} 75$, pp. 19-20. En similar sentido, PADOVANI, Tullio, Diritto Penale, Decima edizione, Milano: Giuffrè, 2012, p. 32.
} 
Polít. crim. Vol. 10, № 19 (Julio 2015), Art. 7, pp. 192-233.

[http://www.politicacriminal.cl/Vol_10/n_19/Vol10N19A7.pdf]

\subsection{Excurso: Pronóstico en torno a los posibles efectos de la Ley de acuerdo de unión civil en su futura relación con el artículo 390 del Código penal.}

Como hemos tenido oportunidad de señalar antes, en enero de 2015 resultó aprobado por el Congreso nacional el proyecto de ley que regula las uniones civiles en Chile. Aun cuando la iniciativa todavía no ha cristalizado en ley oficial, su publicación, se espera, sólo será cuestión de tiempo. ${ }^{80}$ No obstante, a juzgar por el último texto acordado, su contenido ofrecerá probablemente un escenario de luces y sombras.

Por lo pronto, el artículo 1 del mencionado proyecto define esta nueva institución en los términos que siguen:

"El acuerdo de unión civil es un contrato celebrado entre dos personas que comparten un hogar, con el propósito de regular los efectos jurídicos derivados de su vida afectiva en común, de carácter estable y permanente. Los contrayentes se denominarán convivientes civiles y serán considerados parientes para los efectos previstos en el artículo 42 del Código Civil.

Su celebración les conferirá el estado civil de conviviente civil. El término de este pacto restituirá a los contrayentes el estado civil que tenían antes de celebrar este contrato, salvo en la situación prevista en la letra c) del artículo $26 "$.

De la norma transcrita emanan ya algunos de sus elementos constitutivos, a saber: la unión entre dos personas; el carácter estable y permanente de la misma; y el hecho de que ambas compartan un hogar común. De sus siguientes preceptos cabría destacar la posibilidad de que la unión esté constituida por personas de igual o distinto sexo; la exigencia de que los "convivientes civiles" sean mayores de edad y posean la libre administración de sus bienes; el requisito de proceder a su celebración e inscripción ante oficial del Registro Civil; y, en fin, la previsión de impedimentos que lo prohíben por razones de parentesco, vínculo matrimonial no disuelto o acuerdo de unión civil vigente ${ }^{81}$. Dentro de este panorama sinóptico del proyecto, merecen mención también los títulos cuarto y sexto, que regulan los efectos personales y patrimoniales que genera el pacto, como sus causales de término, respetivamente. El título séptimo del proyecto cierra con una serie de modificaciones atingentes a diversos cuerpos legales ${ }^{82}$.

A primera vista, esta normativa parecería llenar algunos de los vacíos denunciados, amén de zanjar otras controversias importantes. Efectivamente, el legislador habría optado por no exigir un período mínimo de convivencia entre los contratantes previo a la inscripción, pero sí al menos su capacidad de ejercicio. Resolvería, al mismo tiempo, la discusión en torno al sexo de los "convivientes civiles", sin establecer limitación alguna en tal sentido. En

\footnotetext{
${ }^{80}$ Con todo, desde ya téngase presente que, de acuerdo al artículo primero de sus disposiciones transitorias, dicha ley establece una vacatio legis de seis meses a contar de su publicación.

${ }^{81}$ Véanse en tal sentido los artículos 5, 7 y 9 del proyecto de ley señalado.

${ }^{82}$ Sobre el particular, interesan las varias alteraciones que se proyecta aplicar al Código penal, y que suponen agregar la figura del "conviviente civil" en las normas correspondientes a las siguientes materias: legítima defensa de parientes, circunstancia mixta de parentesco, encubrimiento de próximos, apertura de correspondencia y la excusa legal absolutoria del artículo 489, entre otras.
} 
GONZÁLEZ, Diego. "El delito de parricidio: consideraciones críticas sobre sus últimas reformas".

contrapartida, dejo de pronunciarse sobre ciertos requisitos motivo de polémica, principalmente en la doctrina civilista, como son el carácter notorio y público de la relación, la supuesta existencia de un vínculo de afecto entre quienes lo celebran -cosa muy distinta a regular los efectos jurídicos de su vida afectiva en común-, y la pretendida índole sexual de la unión.

Ahora bien, para responder el interrogante que aquí interesa, esto es, si puede realmente aplicarse este nuevo instituto al contexto de los delitos de parricidio y femicidio, primero debe descubrirse el verdadero objeto de regulación de esta ley. Ya a partir de su artículo 1, es posible advertir que no pretende establecer una regulación genérica del concubinato en tanto relación de familia. No persigue, en consecuencia, definir el concepto de conviviente, sino algo más restringido que ello: las condiciones para formalizar un acuerdo de unión civil. Con esto quiere subrayarse que el proyecto sólo se limita a regular los acuerdos contraídos por parejas que voluntariamente desean institucionalizar su vínculo, no así al concubinato de hecho, cuyos elementos y efectos continuarían indeterminados. El detalle acusado eventualmente podría representar un serio problema, pues este segundo grupo de casos quizás absorba la mayoría. Una posible explicación frente a aquella circunstancia puede encontrarse en el hecho de que, a pesar de ser consecuencia de una persistente demanda social y de la necesidad de adaptar nuestra legislación de familia a la realidad actual, en términos jurídicos, esta ley se ha propuesto - no de manera exclusiva, aunque sí predominante- fijar los efectos de índole patrimonial que se derivan de tales uniones. Además, la ausencia de una norma interpretativa que haga aplicación general de este concepto, junto con las considerables modificaciones que el texto aprobado aparejaría para otros cuerpos legales, invitan también a pensar que se trata, ciertamente, de una institución inédita en nuestro ordenamiento jurídico. ${ }^{83}$

Si esto es así, cabe entonces preguntarse cuándo podría aplicarse y cuál sería el alcance de la Ley de acuerdo de unión civil para efectos del artículo 390 del Código penal. En principio, y al tenor de lo antes aludido, debería responderse que sólo una vez que aquélla entre en vigencia y respecto de quien tenga, al momento de cometer alguno de estos delitos, la calidad de "conviviente civil" del paciente, quedando excluidos, por tanto, los concubinarios de hecho. De lo contrario, si con objeto de fijar los factores constitutivos de un concubinato no registrado se emplearan los elementos que esta ley contempla para las uniones civiles, se correría el riesgo de efectuar un procedimiento de analogía in malam partem. Con relación a su ámbito de aplicación temporal, sin embargo, es posible explorar dos opciones teóricas que permitirían cuando menos controvertir la conclusión que más arriba se propuso de modo preliminar.

Una primera alternativa discurre sobre la lógica de conceder a esta Ley de acuerdo de unión civil el carácter de ley interpretativa. En tal caso, habría que partir señalando que, conforme a un criterio material, una ley puede ser interpretativa aunque formalmente no se atribuya

\footnotetext{
${ }^{83}$ Revelador sobre este punto es que el artículo 40 del proyecto de ley, que modifica el artículo 108 del Código procesal penal, relativo a las víctimas por asimilación, propone incluir en la letra a) de dicha norma, a continuación de la voz "cónyuge", la expresión "o al conviviente civil”, pero sin eliminar la referencia que su actual letra c) hace al "conviviente". Luego, podría creerse que, de no constituir un grosero olvido legislativo, efectivamente es voluntad de la ley mantener separadas ambas nociones.
} 
Polít. crim. Vol. 10, No 19 (Julio 2015), Art. 7, pp. 192-233.

[http://www.politicacriminal.cl/Vol_10/n_19/Vol10N19A7.pdf]

dicha naturaleza, si su finalidad consiste en esclarecer y fijar el sentido de la ley interpretada $^{84}$. Así, cumplido el supuesto que se trate, además, de una verdadera ley interpretativa, por virtud de una ficción jurídica, quedaría su contenido incorporado al precepto que aclara, permitiendo su aplicación retroactiva cualquiera sea su efecto ${ }^{85}$. En definitiva, siguiendo esta línea podrían superponerse los elementos constitutivos del concepto de "conviviente civil" incluso a hechos perpetrados antes de la efectiva entrada en vigencia de esta ley. Pero ello no sería correcto. Más allá de la ausencia de una declaración formal que le conceda el carácter de ley interpretativa, y de que el proyecto de unión civil en ningún pasaje haga referencia al artículo 390 del Código penal, razones de fondo se oponen a esta salida. En efecto, hemos ya señalado que el propósito de esta ley no es definir el sentido y alcance de la noción de conviviente, sino regular los efectos jurídicos de ciertas parejas que han decidido celebrar dicho contrato. Precisamente por esta razón, la ley en mención viene a introducir principios nuevos que, dada la falta de una regulación previa del concubinato en Chile, no podían considerarse ínsitos en las normas interpretadas ${ }^{86}$.

La otra opción sería entender el problema como genuino ejercicio de interpretación judicial, ya que, en rigor, la cuestión se reduce a dotar de contenido a un elemento típico normativo. Máxime si se considera que pronto, mediante la aprobación de un estatuto legal que finalmente regule las uniones civiles, este elemento normativo del parricidio adquirirá carácter jurídico. Pues bien, como indica el profesor Oliver, las modificaciones que tienen lugar en las normas a que remiten los elementos normativos del tipo también presentan el problema de determinar si pueden o no aplicarse a hechos ocurridos con anterioridad ${ }^{87}$. En su opinión, si para interpretar un elemento normativo del tipo se utilizan normas posteriores al hecho que se juzga, no necesariamente se incurrirá en una infracción formal al principio de legalidad. Esto es así porque, al no tratarse de una ley penal en blanco, el juez no estaría obligado a integrar la ley con tales conceptos, además de que el supuesto de hecho del cual depende la imposición de pena estaría ya establecido con anterioridad a la conducta ${ }^{88}$. No obstante, otro sector doctrinario insiste en guardar de modo absoluto el principio de irretroactividad frente a cualquier modificación gravosa, incluyendo aquellas que afectan a los elementos típicos normativos que remiten a leyes extrapenales, cual sucede en esta ocasión ${ }^{89}$. En el fondo, pues, la decisión sobre este asunto pasará por dilucidar si, en el caso concreto, la extrapolación de los contenidos regulados en La ley de acuerdo de unión civil a hechos ocurridos con anterioridad a su entrada en vigencia, reviste o no un efecto

\footnotetext{
${ }^{84}$ Así, CURY URZÚA, Enrique, Derecho penal: Parte general, $7^{\circ}$ ed., Santiago: Ediciones Universidad Católica de Chile, 2005, p 192.

${ }^{85}$ Cfr. NOVOA MONREAL, Eduardo, Curso de Derecho penal chileno, t. I, $2^{\circ}$ ed., Santiago: Editorial Jurídica Ediar, 1985, pp. 136-137.

${ }^{86}$ Véase al respecto JIMÉNEZ DE ASÚA, Luis, Tratado de Derecho penal, t. II, cit. nota no 66, p. 426.

87 OLIVER CALDERÓN, Guillermo, Retroactividad e irretroactividad de las leyes penales, Santiago: Editorial Jurídica de Chile, 2007, p. 147.

${ }^{88}$ De todos modos, según el autor, lo anterior reconocería como límite los casos en que la variación jurisprudencial es perjudicial, pues en tal evento vulneraría la seguridad jurídica. Cfr. OLIVER, Retroactividad e irretroactividad, cit. nota $\mathrm{n}^{\circ} 87$, pp. 148, 242 y 243.

${ }^{89}$ En este sentido véase BUSTOS RAMÍREZ, Juan; HORMAZÁBAL, Hernán, Lecciones de derecho penal, vol. I, Madrid: Trotta, 1997, p. 106.
} 
GONZÁLEZ, Diego. "El delito de parricidio: consideraciones críticas sobre sus últimas reformas".

perjudicial de tal manera grave que permita incluso fundar la tipicidad de la conducta, en los términos de una analogía in malam partem $^{90}$.

\section{Prescindencia de la ofensa a algún bien jurídico suplementario a la vida del paciente en los parricidios y femicidios relativos a relaciones fenecidas.}

\subsection{Fundamento dogmático del delito.}

Significativas razones hacen que, actualmente, sea más bien aconsejable suprimir la figura autónoma del parricidio. No obstante, todavía hoy en Chile y en otros pocos países, quien derrama la sangre de los suyos se hace acreedor de una pena en extremo severa. Este último dato obliga a seguir inquiriendo cuál es el fundamento dogmático subyacente a la agravación, dejando por un momento al margen su dudosa justificación político-criminal.

Los argumentos esgrimidos en la doctrina nacional, cuanto en la extranjera, se polarizan en dos vertientes generales; de un lado, la que funda el incremento de pena en la mayor culpabilidad del parricida y, de otro, aquella que lo hace gravitar en un plus de lo injusto.

\subsubsection{Argumentos basados en una mayor culpabilidad del parricida.}

En este nivel es posible reunir distintas posturas, cuyo punto de arranque obedece a consideraciones de muy diversa índole (históricas, culturales, biológicas, psíquicas e incluso sentimentales), pero que se reconducen a un factor subjetivo como idea central.

Desde una primera perspectiva, se propugna que la gravedad del delito de parricidio reposa en el plus característico de horror y reproche inseparable del tipo legal. El hechor violaría no sólo la ley escrita, sino también una realidad biológica ${ }^{91}$. En definitiva, esta tesis resalta el carácter irracional de la conducta, que inevitablemente trae a la memoria la concepción primitiva del delito.

Algunos complementan la noción de atentado contra la naturaleza con una total ausencia de misericordia y humanidad en el parricida. Así, respecto de la figurada ya derogada en España, Muñoz Conde pensaba que "no cabe la menor duda que no es lo mismo matar a otra persona cualquiera que al propio padre o hijo, desconociendo llamamientos de la naturaleza y sentimientos de piedad de la más ancestral raigambre" ${ }^{\prime 92}$.

Bajo un discurso más extremo, no faltaron quienes asociaron a la acción parricida una mayor peligrosidad del agente. Aquel que comete parricidio, se dice, habría de encontrar

\footnotetext{
${ }^{90}$ Así, por ejemplo, para quienes están convencidos de que la expresión "conviviente" empleada por el artículo 390 sólo incluye parejas heterosexuales, claramente envolvería efectos perjudiciales la aplicación analógica del nuevo estatuto propuesto por la Ley de acuerdo de unión civil.

${ }^{91}$ QUINTANO RIPOLLÉS, Tratado de la Parte especial, cit. nota no ${ }^{\circ}$, pp. 141-142.

${ }^{92}$ MUÑOZ CONDE, Francisco, Derecho penal: Parte especial, Sevilla: Publicaciones de la Universidad de Sevilla, 1976, p. 34.
} 
Polít. crim. Vol. 10, No 19 (Julio 2015), Art. 7, pp. 192-233.

[http://www.politicacriminal.cl/Vol_10/n_19/Vol10N19A7.pdf]

menos reparos o trabas morales para la comisión delictiva en los extraños, de manera que la defensa social exigiría una mayor sanción o castigo ${ }^{93}$.

Un gran sector de la doctrina explica la agravación a partir del quebrantamiento de supuestos lazos de afecto que se entretejen en las relaciones de familia. En consecuencia, atentar contra la vida de un próximo permitiría formular un juicio de reproche más intenso, ya que se desobedecen normas subjetivas de determinación. Para algunos, dicha idea descansa sobre la presunción legal de que los vínculos de parentesco originan naturalmente una comunidad de afectos y sentimientos ${ }^{94}$. Para otros, como Bacigalupo, lo protegido serían "reales relaciones parentales generadoras de confianza y afecto entre las personas, y no la existencia de simples vínculos jurídicos"95. Esta última tesis, todavía muy difundida en nuestros días, evoca el pensamiento de quienes ven en el desarrollo de relaciones de confianza y dependencia la posibilidad de cometer actos de violencia ${ }^{96}$.

\subsubsection{Crítica a las tesis anteriores. El parricidio como delito pluriofensivo.}

El reproche y conmoción general que despierta el parricidio no aporta elementos jurídicos que justifiquen su existencia. Que el delito desatienda los llamados de la naturaleza -como expresó la propia Comisión redactora del Código penal chileno- ${ }^{97}$ o que olvide por completo los sentimientos mínimos de piedad, son afirmaciones que poca seguridad dogmática pueden ofrecer, y más bien conducen a tomas de postura emocionales ${ }^{98}$.

Por otro lado, que la conducta parricida revele una mayor peligrosidad en el reo parece inadmisible en un Derecho penal de acto. Además, los contextos que rodean la comisión de estos crímenes son relaciones averiadas, de suerte que no necesariamente denotarán una predisposición delictiva. Y la peligrosidad tampoco es un concepto graduable ${ }^{99}$, por ende, difícil será demostrar en qué medida un parricida es más peligroso que un simple homicida.

Respecto de los vínculos de afecto que se fraguan al abrigo de una relación de familia, entre nosotros, Sergio Politoff hace tiempo se había resuelto firmemente contrario a fundar la excesiva penalidad del maleficio en una mera ficción ${ }^{100}$. Podrá aceptarse que comúnmente

\footnotetext{
${ }^{93}$ Así se aprecia ya en CARRARA, Francesco, Programa de Derecho criminal, t. III, $2^{\mathrm{a}}$ ed., Trad.: ORTEGA, J., Bogotá: Temis, 1967, p. 160. Cfr. asimismo ALIMENA, Bernardino, Delitos contra la persona, Bogotá: Temis, 1975, p. 187.

${ }^{94}$ Cfr. DEL ROSAL, Juan; COBO, Manuel; RODRÍGUEZ MOURULLO, Gonzalo, Derecho penal español, t. III, Madrid: Imprenta Aguirre, 1962, pp. 162-163.

${ }^{95}$ BACIGALUPO, Enrique, Estudios sobre la Parte especial del Derecho penal, 2a ed., Madrid: Akal, 1994, p. 53.

${ }_{96}$ Así, MATUS; RAMÍREZ, Lecciones de Derecho penal, cit. nota $n^{\text {o }} 33$, p. 64. Cabe tener presente que, para estos autores, dicha circunstancia determinaría una especial antijuridicidad en el delito. Con todo, en los casos de víctimas mujeres, la agravación se fundaría en la reprobada manifestación de rasgos patriarcales atávicos.

${ }^{97}$ Cfr. Código penal de la República de Chile, cit. nota ${ }^{\circ}$ 8, p. 398.

${ }^{98}$ Fuera de esto, no se exige una motivación especial en el parricida; tan sólo se pide que conozca las relaciones que lo ligan con la víctima. Cfr. FIGUEIREDO DIAS, Jorge, "Artigo 132”, en: DEL MISMO (Dir.), Comentário Conimbricense do Código Penal, t. I, Coimbra: Coimbra Editora, 1999, pp. 24-46, p. 29.

${ }^{99}$ RIVACOBA, Manuel, Nueva crónica del crimen, Valparaíso: Edeval, 1981, p. 224.

${ }^{100}$ Cfr. POLITOFF, Sergio, "Sentencias comentadas", $R C P$, t. XXIV, no 3 (1965), pp. 231-241, pp. 236 y 237.
} 
GONZÁLEZ, Diego. "El delito de parricidio: consideraciones críticas sobre sus últimas reformas".

estos lazos de aprecio existen, pero comprendiendo a la vez que nada tienen de indispensable; habrá casos en que jamás los hubo o bien se extinguieron en el devenir. A mayor abundamiento, las falencias en esta materia son notorias, desde que la figura sólo alcanza a los consanguíneos, marginando a la relación de adopción ${ }^{101}$, en circunstancias que ésta puede generar igual o mayores nexos que aquélla, considerando que la paternidad se asume voluntariamente. Y, en definitiva, aunque existan tales lazos, el Derecho no puede ni debe entrar a valorar elementos tan abstractos como el afecto o el amor -cuya exigencia forzada, dicho sea de paso, los torna inútiles-, ni tampoco presuponer la perversidad o malignidad en las personas.

Por lo anterior, resultaría acaso sobreabundante pronunciarse sobre la pretendida suposición legal de tales vínculos, empero, conviene añadir dos puntos. Primero, esta presunción iuris et de iure significaría un atropello palmario del principio de culpabilidad, razón por la cual es prácticamente unánime su rechazo ${ }^{102}$. En segundo lugar, presumir una mayor culpabilidad en el acto parricida importa ignorar por entero la realidad criminológica en que se desenvuelve. La evidencia empírica revela que estos hechos de sangre, lejos de venir presididos por una conducta más reprochable, habitualmente son amargo desenlace de un continuo proceso de degradación familiar ${ }^{103}$. Por el contrario, entonces, la exigibilidad de otra conducta muy a menudo se encontrará limitada.

Para terminar, la discusión en torno a la faz subjetiva del parricidio, podría agregar un obstáculo común a las tesis hasta ahora analizadas. En efecto, de acogerse la opción que extiende la aplicación del parricidio a hipótesis en que el resultado de muerte no ha sido buscado por el hechor, se dificultaría sobremanera la comprensión de este asunto como uno de mayor culpabilidad ${ }^{104}$.

En cambio, la mayor gravedad del parricidio en relación con el homicidio simple reside en un plus de antijuridicidad. Aunque en esta vertiente tampoco se enlistan teorías totalmente unitarias $^{105}$, se estima correcta aquella que discurre sobre una base estrictamente objetiva, y

${ }^{101}$ DONNA, Edgardo, Derecho penal: Parte especial, t. I, $3^{\mathrm{a}}$ ed., Buenos Aires: Rubinzal-Culzoni, 2008 , p. 29.

102 DÍEZ RIPOLLÉS, José Luis; GRACIA MARTÍN, Luis, Delitos contra bienes jurídicos fundamentales: vida humana independiente y libertad. Valencia: Tirant lo Blanch, 1993, p. 152. Por cierto, esta presunción desconoce, además, que en ciertos casos el sujeto puede dar muerte a uno de los suyos, guiado, precisamente, por estos vínculos de aprecio, como ocurre en las muertes por piedad.

${ }^{103}$ MORALES PRATS, Fermín, "Del homicidio y sus formas”, en: QUINTERO OLIVARES, Gonzalo (Dir.), Comentarios a la Parte especial del Derecho penal, 6ª ed., Navarra: Aranzadi, 2007, pp. 31-83, p. 48.

104 Para una exposición del problema y solución en favor de la admisión del dolo eventual, véase OSSANDÓN, María Magdalena, "La faz subjetiva del tipo de parricidio", Revista de Derecho (Valparaíso), n ${ }^{o}$ XXXIV (2010), pp. 415-457. Cfr. asimismo, LABATUT, Gustavo, Derecho Penal, t. II, $7^{\text {a }}$ ed. actualizada por ZENTENO, Julio, Santiago: Editorial Jurídica de Chile, 1996, p. 165.

${ }_{105}$ Así, para algunos, lo que incrementaría la antijuridicidad del hecho es un desvalor de acción, derivado del incumplimiento de deberes jurídicos específicos. Cfr. CEREZO MIR, José, Curso de Derecho penal español: Parte general, t. II, 6 ed., Madrid: Tecnos, 2000, p. 403; y también VAN WEEZEL, Alex, "Lesiones", cit. nota $\mathrm{n}^{\circ} 29$, p. 245. Otros entienden que dicho plus se verifica tanto en el desvalor de acción como en el de resultado. En este último sentido, MIR PUIG, Santiago, Derecho penal: Parte general, $7^{\mathrm{a}}$ ed., Barcelona: Repertor, 2005, p. 629; y así también MORALES PRATS, "Del homicidio”, cit. nota n 103, p. 48. 
Polít. crim. Vol. 10, № 19 (Julio 2015), Art. 7, pp. 192-233.

[http://www.politicacriminal.cl/Vol_10/n_19/Vol10N19A7.pdf]

que, por ende, explica la diferencia entre el parricidio y su figura básica en función de los bienes jurídicos que cada uno lesiona.

Este incremento material de lo injusto no se debe, como han defendido algunos, al hecho de que matar a un cercano sea en realidad más grave que destruir la vida de otro individuo ${ }^{106}$. Objetivamente, una y otra existencia, tienen el mismo valor. Más bien, se explica del siguiente modo: junto con atentar contra la vida del paciente, el acto parricida infringe otros bienes jurídicos suplementarios. Dicho objeto adicional de tutela representa ciertos intereses de índole familiar, cuyo resguardo se impone mediante el cumplimiento de deberes especiales de protección, reverencia, ayuda mutua y respeto recíproco, oriundos del Derecho de familia $^{107}$. Tales deberes no tienen un carácter genérico, sino que ordenan la armonía al interior de relaciones específicas que, comúnmente, sirven de base a la organización familiar ${ }^{108}$.

En concreto, la mayor pena en la muerte de un ascendiente o descendiente, responde a la infracción de los deberes dispuestos en los artículos 222 y siguientes del Código civil. En cuanto a los cónyuges, se quebrantan obligaciones derivadas de los efectos personales del matrimonio, reglados en los artículos 131 y siguientes del mismo cuerpo. Tratándose de los concubinarios, se violan idénticos deberes personales, pero de origen convencional, pues se extraen de los mismos elementos constitutivos de la unión, dictados con motivo de una sana convivencia en común ${ }^{109}$. Luego, el parricidio es un delito pluriofensivo ${ }^{110}$.

Probablemente la objeción más importante contra esta línea argumental la formuló tiempo atrás Bajo Fernández. A propósito de la circunstancia mixta de parentesco, el penalista ibérico denunció que esta tesis no permitiría explicar por qué a veces la infracción de tales deberes no agrava la responsabilidad penal sino que la atenúa ${ }^{111}$ Es muy probable que dicha

\footnotetext{
${ }^{106}$ Así, sin embargo, GARRIDO MONTT, Derecho penal, cit. nota n o 55, p. 72, quien patrocinó la existencia de un mayor injusto, argumentando que la muerte de un pariente o cónyuge es más grave que la de cualquier otra persona, pues el artículo 1 de la Constitución alzaprima a la familia como núcleo fundamental de la sociedad. No comulgamos con dicha opinión. La norma que cita parece una declaración de principios de la que no se sigue forzosamente el valor superior de la vida de familiares en desmedro de extraños.

107 En este sentido, véase DÍEZ RIPOLLÉS; GRACIA MARTIN, Delitos contra bienes jurídicos fundamentales, cit. nota no 102, p. 153; y GUALLART DE VIALA, "Parricidio", cit. nota nº 5, p. 928.

108 A propósito de la circunstancia mixta de parentesco, CURY, Derecho penal, cit. nota n ${ }^{\circ} 84$, pp. 546-547, extrae una importante consecuencia, por cuanto, en su criterio, siendo ésta una cuestión concerniente a la antijuridicidad del hecho, en general no debería agravarse la pena cuando el agente ha sido provocado por el ofendido. Puesto que "en tales situaciones el atacado ha vulnerado ya la deferencia exigida para el vínculo parental, no es razonable reclamar del agresor que la guarde a todo trance".

${ }^{109}$ Para el régimen actual de tales deberes, véase TURNER, Susan, "La unión de hecho como institución del Derecho de familia y su régimen de efectos personales”, Ius et Praxis, año 16, no 1 (2010), pp. 85-98, pp. 92 y ss. Sobre su regulación en la Ley de acuerdo de unión civil, véase el artículo 14 del texto aprobado.

${ }^{110}$ Así POLITOFF, Sergio; GRISOLÍA, Francisco, BUSTOS, Juan, Derecho penal. Parte especial: Delitos contra el individuo en sus condiciones físicas, $2^{\mathrm{a}}$ ed., Santiago; Editorial Jurídica Congreso, 2006, p. 117; DEL VILLAR BRITO, Waldo, Manual de Derecho penal: Parte especial, Valparaíso: Edeval, 2009, p. 67; DONNA, Derecho penal, cit. nota $\mathrm{n}^{\circ}$ 101, p. 29; NÚÑEZ, Ricardo, Tratado de Derecho penal, t. III, Córdoba: Lerner, 1978, p. 31; y, recientemente, AROCENA, Gustavo; CESANO, José, El delito de femicidio: aspectos político-criminales y análisis dogmático-jurídico, Buenos Aires-Montevideo: B de F, 2013 , p. 73.

${ }^{111}$ BAJO FERNÁNDEZ, Miguel, El parentesco en el Derecho penal, Madrid: Universidad Autónoma de Madrid, 1972, p. 30.
} 
GONZÁLEZ, Diego. "El delito de parricidio: consideraciones críticas sobre sus últimas reformas".

disfunción se deba a la vieja y rígida distinción entre delitos ejecutados contra personas o sobre cosas, que servía de base para determinar los efectos penales del parentesco ${ }^{112}$. Ahora, respecto de la crítica, cabe señalar que si el parentesco puede operar como atenuante o eximente, la justificación habrá de buscarse en una menor culpabilidad, no en una cuestión de injusto, y de ahí que su análisis prescinda de la infracción a tales deberes ${ }^{113}$.

Pues bien, si el fundamento del parricidio como tipo agravado mora en la infracción de ciertos deberes especiales, es de toda lógica preguntarse qué sucede cuando se disuelve o desaparece la fuente generadora de éstos (matrimonio o concubinato). Como vimos, tras la última reforma, el asunto adquiere notable interés, vista la inclusión de dos nuevos sujetos pasivos: quien ha sido cónyuge o conviviente del hechor. Por lo pronto, anticipemos las tres posibles respuestas a este interrogante. La primera sería entender que la explicación de los nuevos supuestos guarda relación con las hipótesis originales, ya que, pese a la disolución del vínculo, los deberes personales subsistirían. Por extinguirse todo género de obligaciones entre los sujetos, la segunda alternativa es razonar sobre un fundamento distinto para los casos recientemente incluidos. Descartando esta pareja de posibilidades, la tercera supone admitir que la incorporación de relaciones pasadas en el parricidio carece de justificación.

\subsection{Crítica a la extensión del tipo a los ex cónyuges y ex convivientes.}

Los efectos personales derivados del matrimonio y del concubinato divergen en cuanto a su fuente, pero tienen similar contenido. Y en ambos casos, los deberes se imponen al servicio de un objetivo superior, que es la realización de los fines propios de la unión marital o de hecho. ${ }^{114}$ Como es de imaginar, la vigencia de estos mandatos está condicionada a la subsistencia de la relación de familia que los generó.

A un lado el caso de muerte de un cónyuge, se termina el matrimonio por sentencia firme que declara su nulidad o el divorcio; donde la primera retrotrae a los presuntos casados al estado previo a contraer el vínculo anulado y la segunda apareja la disolución del yugo junto con los efectos determinados por sus fines ${ }^{115}$. Por lo que hace al concubinato, además de terminarse debido a la muerte de un compañero o por el hecho de contraer matrimonio, se extingue por la simple ruptura. En este evento, uno o más de sus elementos constitutivos

\footnotetext{
${ }^{112}$ Para una exposición de esta doctrina, véase PACHECO, Joaquín Francisco, El Código penal concordado y comentado, t. I, $6^{\mathrm{a}}$ ed., Madrid: Manuel Tello, 1888, p. 245.

${ }^{113}$ Cfr. RIVACOBA, Manuel, "Las circunstancias modificativas de la responsabilidad criminal en la teoría general del delito", en: SERRANO, Alfonso et al., Estudios de derecho penal y criminología en homenaje al Profesor José María Rodríguez Devesa, t. I, Madrid: Facultad de Derecho de la Universidad Nacional de Educación a Distancia, 1989, pp. 183-210, p. 206.

${ }^{114}$ Cfr. TRONCOSO, Hernán, Derecho de familia, 9a ed., Santiago: LexisNexis, 2006, p. 113.

115 Véanse, respectivamente, los artículos 50 y 53 de la Ley No 19.947. Cfr. además BARRIENTOS, Javier, Derecho de las personas: Derecho matrimonial, Santiago: LegalPublising, 2011, pp. 747-748.

Por otro lado, el derecho a solicitar la desafección de los bienes declarados familiares y la pérdida del derecho de alimentos, dan fe de la extinción del deber personal de socorro. Lo mismo ocurre con el derecho a contraer nuevas nupcias, tratándose del deber de fidelidad. Y es que mantener a los ex cónyuges atados a esta clase de exigencias jurídicas, de notorio trasfondo ético, constituiría una auténtica cortapisa para su libre realización personal, tornando ineficaz el ius conubii recuperado. En adición a lo dicho, algunos deberes, y especialmente el de respeto recíproco, sirven al objeto de proyectar una convivencia armoniosa al interior de la familia, por lo que resulta injustificado exigir su cumplimiento una vez desaparecida la realidad material que los inspiraba.
} 
Polít. crim. Vol. 10, No 19 (Julio 2015), Art. 7, pp. 192-233.

[http://www.politicacriminal.cl/Vol_10/n_19/Vol10N19A7.pdf]

deja de concurrir, siendo indiferente su índole consensuada o unilateral ${ }^{116}$. Lo importante es que la sola voluntad de al menos uno de sus miembros, permite presumir una renuncia a los deberes íntimos que buscaban favorecer una sana convivencia en común. La extinción de los deberes personales entre ex cónyuges o ex concubinarios será, entonces, consecuencia natural del prístino adagio de que lo accesorio sigue la suerte de lo principal $^{117}$.

De otra parte, no es posible recoger un bien jurídico de la sola existencia de una relación pasada, ni desatender únicamente para efectos penales que tales deberes se extinguieron ${ }^{118}$. Esta ficción contradice la conexión lógica que enlaza a los Derechos civil y penal. Además, si se entiende que tales deberes de respeto, ayuda mutua y protección subsisten incluso después de la disolución del vínculo, también tendría que aceptarse la continuidad de la posición de garante que el matrimonio y el concubinato crean, lo cual no parece razonable. Por este motivo, aun cuando desde una óptica social -en sí misma relativa- pueda interpretarse que en ciertos casos el vínculo familiar perdura, nos parece, pues, que la normativización del parentesco, como concepto jurídico que es, tiene sus límites.

Las inconsistencias dogmáticas larvadas en la enmienda fueron advertidas por varios académicos invitados a comentar el proyecto ${ }^{119}$. Frente a esta dificultad, resultaba necesaria la propuesta de argumentos que la justificaran desde otra perspectiva, con lo cual llegamos al examen de la segunda respuesta sugerida más arriba.

Durante el debate parlamentario se insistió en que el sentido de la enmienda era establecer una discriminación positiva en favor de la mujer ${ }^{120}$, y que es la vulnerabilidad física de ésta lo que funda el mayor reproche ${ }^{121}$. No obstante, en ambas opciones se olvida que el tipo no excluye a la mujer y que, por ende, ésta puede cometer parricidio cuando da muerte a quien fue su cónyuge o conviviente. Más importante todavía, nuestro catálogo de circunstancias agravantes, ya contemplaba la de abusar el delincuente de la superioridad de su sexo o de

\footnotetext{
${ }^{116}$ DONOSO; RIOSECO, El concubinato, cit. nota n ${ }^{\circ}$ 50, p. 21.

117 Algo similar ocurría en el delito de adulterio, donde el deber de fidelidad se entendía justificado sólo en subsistencia del matrimonio, que no en caso de separación, y mucho menos luego de roto el vínculo.

118 Así, sin embargo, AROCENA/CESANO, El delito de femicidio, cit. nota ${ }^{\circ} 110$, p. 74, quienes ven su fundamento "en el menosprecio del respeto que se deben mutuamente los ex esposos o las personas que han mantenido una relación afectiva". Por otra parte, CORN, Emanuele, "La revolución tímida. El tipo de femicidio introducido en Chile por la Ley N 20.480 desde una perspectiva comparada", Revista de Derecho de la Universidad Católica del Norte, n $\mathrm{n}^{\mathrm{o}} 2$ (2014), pp. 103-136, p. 126, sostiene que la extensión del tipo a ex cónyuges y ex convivientes "subraya cómo el vínculo familiar se mantiene en el tiempo después del término establecido por el Derecho civil, tanto a nivel social como para el Derecho penal".

${ }^{119}$ En tal sentido se manifestaron los profesores Raúl Carnevali Rodríguez, José Luis Guzmán Dalbora y Juan Domingo Acosta. BIBLIOTECA NACIONAL, Historia de la Ley $N^{o} 20.480$, cit. nota $\mathrm{n}^{\circ} 30$, pp. 69 , 164 y 359.

${ }^{120}$ BIBLIOTECA NACIONAL, Historia de la Ley $N^{o}$ 20.480, cit. $n^{\circ}$ 30, p. 289. Cfr. TOLEDO, Patsilí, Feminicidio, México D.F.: Organización en México del Alto Comisionado de las Naciones Unidas, 2009, p. 72, quien entiende que la pluriofensividad del delito está determinada por una infracción a la prohibición de conductas discriminatorias en las relaciones íntimas.

${ }^{121}$ BIBLIOTECA NACIONAL, Historia de la Ley $N^{\circ}$ 20.480, cit. no 30, p 248. Así también, MERA FIGUEROA, Jorge, "Femicidio", en: RED CHILENA CONTRA LA VIOLENCIA DOMÉSTICA Y SEXUAL, Tipificación del femicidio en Chile: un debate abierto, Santiago: Red Chilena contra la violencia doméstica y sexual, 2009, pp. 53-57, p. 55, en cuya opinión la especificidad de estos hechos está dada por la vulnerabilidad de la mujer, pero como elemento determinante de un mayor injusto.
} 
GONZÁLEZ, Diego. "El delito de parricidio: consideraciones críticas sobre sus últimas reformas".

sus fuerzas, amén de que la ventaja física del varón, y sobre todo su empleo en el caso concreto, no son elementos cuya presencia puedan presuponerse alegremente sin más.

Según otros, tales hechos vulnerarían fuertes vínculos de confianza entre sujetos que han compartido una vida en común; opinión relativamente aceptada en doctrina ${ }^{122}$. Esta idea no es convincente, por cuanto la confianza y el afecto, huelga decir, perfectamente pueden faltar, con mayor razón si existen denuncias previas de violencia intrafamiliar. Y si, en definitiva, lo que se pretendía era agravar la responsabilidad de aquel que aprovecha sus relaciones pretéritas con la víctima, para encontrar formas y ocasiones ventajosas de consumar el hecho, habría bastado con recurrir al asesinato por alevosía.

Recientemente se añade la opinión de los profesores Jean Pierre Matus y María Cecilia Ramírez, quienes consideran que en la muerte de la ex cónyuge o ex conviviente, se verifica una manifestación de violencia de género, en sí misma objeto de protección y sanción penal autónomos, lo cual impide calificar el hecho como homicidio simple ${ }^{123}$. Sin embargo, esta tesis tampoco explica por qué la agravación alcanza por igual a la mujer. Además, el Código penal chileno, a diferencia de otros, configuró un tipo de femicidio "íntimo", restricción ésta que no podría empatarse si su intención hubiese sido castigar actos de violencia de género, donde el agresor perfectamente puede ser un extraño ${ }^{124}$.

En repetidas oportunidades se ha mencionado que en general medidas de esta índole tienen por objeto reforzar la protección de la dignidad humana ${ }^{125}$. Es con absoluta seguridad la postura menos contundente, toda vez que no debe confundirse este atributo de la persona con los elementos que posibilitan su conservación, respecto de los cuales aquélla únicamente sirve como concepto de referencia o principio regulativo ${ }^{126}$.

En cambio, nos parece que, dentro de las alternativas propuestas, la exigencia de hijos en común entre los sujetos quizás habría guardado mayor justificación ${ }^{127}$. Como es sabido, el quiebre de la unión matrimonial o de hecho en nada altera los efectos derivados de la relación filial. Al padre, por ejemplo, no sólo cabe un deber de protección respecto de su hijo, sino la obligación de velar por su mayor realización material y espiritual posible,

122 BIBLIOTECA NACIONAL, Historia de la Ley $N^{o}$ 20.480, cit. $\mathrm{n}^{\mathrm{o}} 30$, p. 459. Cfr. VARGAS; SANTIBÁÑEZ, "Reflexiones", cit. nota $\mathrm{n}^{\circ} 34$, p. 205, quienes consideran que, por existir conocimiento, confianza y cariño, "la víctima está en una posición de mayor debilidad, con menos posibilidades de repeler la ofensa”. Así también BALMACEDA, Manual de Derecho penal, cit. nota $\mathrm{n}^{\circ}$ 57, p. 46, para quien, por semejantes motivos, la víctima se encuentra en un mayor estado de indefensión.

${ }^{123}$ MATUS/RAMÍREZ, Lecciones de Derecho penal: Parte especial, cit. nota ${ }^{\circ}$ 33, p. 81.

${ }^{124}$ Verbigracia, el artículo $80 \mathrm{~N}^{\mathrm{o}} 11$ del Código penal argentino, exige expresamente que medie violencia de género, pero, en contrapartida, el hecho puede ser perpetrado por un hombre contra indeterminada mujer.

${ }^{125}$ En España, muchos creen que éste sería el bien jurídico protegido en los tipos de violencia doméstica. Así, por muchos, MORILLAS, Lorenzo, "Valoración de la violencia de género desde la perspectiva del Derecho penal", RECPC, no 4 (2002), p. 16, en: http://criminet.ugr.es/recpc/recpc 04-06.pdf [visitado el 02.11.2014].

${ }^{126}$ Cfr. GUZMÁN DALBORA, "Dignidad humana, bienes jurídicos y fin de la pena en Werner Maihoffer", en: DEL MISMO, Figuras y pensamientos, cit. nota ${ }^{\circ} 46$, pp. 161-185, pp. 170 y ss.

${ }^{127}$ En este sentido, el informe entregado por la Comisión de familia. No obstante, la Comisión mixta concluyó que establecer listados de condiciones era una invitación para que el juez riguroso en la aplicación de la ley estricta nunca la aplique. Cfr. BIBLIOTECA NACIONAL, Historia de la Ley $N^{\circ} 20.480$, cit. n ${ }^{\circ} 30$, p. 457. 
Polít. crim. Vol. 10, № 19 (Julio 2015), Art. 7, pp. 192-233.

[http://www.politicacriminal.cl/Vol_10/n_19/Vol10N19A7.pdf]

esfera claramente afectada si aquél da muerte a la madre de éste. En Chile, estas situaciones parecen adquirir relevancia meramente al fijarse la extensión del mal causado.

Así las cosas, la dificultad de cohonestar esta extensión típica revela que, en estricto rigor, su razón de ser no es sino la excusa de castigar con la mayor drasticidad posible al que segó la vida de otro con quien mantuvo un vínculo previo ${ }^{128}$. En ese caso, serían consideraciones de orden político-criminal las que motivan y definen la calificación agravada de estas nuevas hipótesis ${ }^{129}$, estremeciendo sensiblemente el terreno de la proporcionalidad. Va de suyo que una explicación de este tenor es muy deficitaria, y no ofrece justificación alguna para una elevación de pena tan considerable.

Sentado lo anterior, apresurémonos a registrar que la fórmula escogida tampoco fue la más precisa. La ausencia de algún límite temporal luce manifiesta en el lacónico tipo: "quien es o ha sido su cónyuge o su conviviente", cuestión que, en principio, permitiría incluir una constelación de casos con dudosa justificación. Esto sucederá cuando la relación entre los sujetos fue intrascendente, pasajera o muy remota en el tiempo. Por ejemplo, parece excesivo castigar a título de femicidio a quien da muerte a una novia con la que vivió seis meses hace veinte años, habiendo contraído matrimonio posteriormente con una persona distinta, a la que sigue unido, y sin que la relación pasada tuviere conexión alguna con el homicidio perpetrado.

Con este recaudo, otros países sí han dispuesto restricciones mínimas, que, a pesar de arrastrar la arbitrariedad que subyace a todo plazo, ofrecen mayor certeza. En este sentido, el artículo 112 del Código penal costarricense exige que los concubinarios hayan llevado vida marital por lo menos durante los dos años anteriores a la perpetración del hecho. En tanto que el Código penal suizo, a propósito de las lesiones simples (artículo 123), las vías de hecho (artículo 126) y las amenazas (artículo 180), sólo comprende conductas que tienen lugar hasta un año después del divorcio o de la disolución de la unión registrada.

No obstante, antes de pensar que el legislador olvidó meditar sobre este importante punto, deberá sospecharse si acaso derechamente se le sacrificó en pos de asegurar su aplicación práctica $^{130}$. Así y todo, una interpretación sensata impondrá al juez valorar la relevancia del vínculo, exigiendo de él un tiempo razonable de duración y cierta proximidad entre su disolución y la época de comisión del delito; de otro modo, habrá de castigarse al sujeto por

\footnotetext{
${ }^{128}$ Así también ÍÑIGO, Elena, "Fundamento del efecto modificador de la responsabilidad penal de la relación de parentesco", InDret, $\mathrm{n}^{\circ} 4$ (2011), p. 6, nota marginal $\mathrm{n}^{\circ} 16$, quien, a propósito de la circunstancia mixta de parentesco española, considera que la justificación de la cláusula de cierre referida a las relaciones pasadas, simplemente se ciñe a la pretensión del legislador por abarcar los supuestos más habituales.

${ }^{129}$ En el mismo sentido del texto, SALINERO, "El femicidio", cit. nota n ${ }^{\circ} 55$, p. 13, quien señala que "en las relaciones de convivencia, y sobre todo en las que cesaron, la posibilidad de encontrar un bien jurídico, adicional a la vida, es tanto o más difícil que hallar una aguja en un pajar".

${ }^{130}$ Antes del informe de la primera Comisión de Constitución, el proyecto contenía una limitación temporal, siquiera respecto de los convivientes. Según ésta, se excluía a quienes habían cesado efectivamente su vida en común con, a lo menos, tres años de anterioridad a la ejecución del delito, salvo que existiesen hijos comunes. Las desavenencias acerca de por qué tres años y no más, junto con la crítica de incorporar plazos basados en acciones civiles -éste es el término que debe transcurrir para demandar unilateralmente el divorcio-, determinaron la supresión de esta reserva.
} 
GONZÁLEZ, Diego. "El delito de parricidio: consideraciones críticas sobre sus últimas reformas".

el tipo básico ${ }^{131}$. Parece demasiado gravoso confiar estos casos sencillamente a una aplicación criteriosa del artículo 68.

\section{Valoración global de la política criminal empleada.}

\section{1. ¿Una manifestación de Derecho penal simbólico?}

Que las leyes penales presenten un marcado tinte simbólico es una idea que se degrada hasta la evidencia. Es innegable que esta clase de normas generan efectos muy elocuentes en la inteligencia de los individuos; tanto por el lenguaje del que se sirven, su carga de desaprobación y reproche, y por el mal, muchas veces severo, con que amenazan a su potencial infractor ${ }^{132}$. Aclarado lo cual, asomarán los problemas cuando deliberadamente se utilice al Derecho penal como mero aparato de comunicación social, dirigido sólo a producir impacto en la opinión pública o con el exclusivo designio de tranquilizar al ciudadano $^{133}$. De ello se seguirá un descuido en el castigo de conductas ofensivas de bienes jurídicos, que es, con todo, su función principal. En sentido crítico, por tanto, las leyes penales puramente simbólicas surgen en momentos de convulsión política, económica o social, con el afán de proyectar una imagen diligente y resuelta de los poderes públicos, mientras éstos se limitan a transmitir mensajes valorativos, cuya "capacidad de influencia quedaría confinada a las mentes o a las conciencias, en las que producirían emociones o, cuando más, representaciones mentales." ${ }^{134}$. Nada de extraño tendrá que tales medidas encuentren asilo en delitos que fácilmente conmueven a la colectividad. Y así será el caso con las leyes que sancionan la violencia doméstica y de género, si son sólo fruto de políticas motivadas por la intensa presión social que las rodea y los estados de ánimo dominantes a la sazón. El resultado no es otro que conceder vida jurídica a tipos autónomos o calificados, que por ineficaces son también innecesarios ${ }^{135}$.

En las reformas que afectan la configuración actual del parricidio inciden una plétora de componentes con contenido simbólico. En esta línea, el hecho que la Ley No 20.066, en su

131 Cfr. MIR PUIG, Santiago, Derecho penal, cit. nota $\mathrm{n}^{\circ} 105$, p. 629, quien destaca que semejante razonamiento ha conducido al Tribunal Supremo español a descartar la aplicación de la circunstancia mixta de parentesco, cuando éste pierde su significado de vinculación entre los sujetos. En tanto que, según BALMACEDA, Manual de Derecho penal, cit. nota $n^{\circ}$ 57, p. 46, en dichos casos, "esta consideración queda al arbitrio del juez, quien es el que deberá determinar si la pena con la que se castigue al autor del delito tiene fundamentos para ser más dura que las de un homicidio".

${ }^{132}$ Véase al respecto RIVACOBA, Manuel, La retribución penal, Santiago: Conosur, 1995, pp. 63 y 64. Aunque debe aclararse, como dice Mañalich, que esto no significa que la expresión institucional del reproche no pueda manifestarse a través de otros símbolos convencionales distintos de la pena. Cfr. MAÑALICH, Juan Pablo, Terror, pena y amnistía, Santiago: Flandes Indiano, 2010, p. 83.

${ }^{133}$ SILVA SÁNCHEZ, Aproximación, cit. nota nº 67, p. 482.

134 DÍEZ RIPOLLÉS, José Luis, "El Derecho penal simbólico y los efectos de la pena”, Boletín mexicano de Derecho comparado, vol. XXXV, n 103 (2002), pp. 63-97, p. 68.

${ }^{135}$ Diversas monografías sobre la materia sitúan a esta clase de medidas como paradigma de respuesta penal puramente simbólica. Así, DÍEZ RIPOLLÉS, "El Derecho penal simbólico", cit. nota n 134, p. 93, las etiqueta como "leyes promotoras", incardinadas en la supuesta función ético-social que desempeñaría el Derecho penal. En la clasificación propuesta por HASSEMER, Winfried, "Derecho penal simbólico y protección de bienes jurídicos”, en: BUSTOS, Juan (Dir.), Pena y Estado, Santiago: Conosur, 1995, pp. 2336 , p. 26, estas leyes se encuadran en lo que él denomina "respuestas sustitutorias del legislador", esto es, cuerpos legales que sólo sirven de coartada o pretexto ante la queja general. 
Polít. crim. Vol. 10, № 19 (Julio 2015), Art. 7, pp. 192-233.

[http://www.politicacriminal.cl/Vol_10/n_19/Vol10N19A7.pdf]

artículo 1, asuma la presuntuosa vocación de "prevenir, sancionar y erradicar la violencia intrafamiliar" "136, es expresión de la tendencia aludida. Así también que en su artículo 4 enfatice la preocupación por realzar la dignidad de la mujer, para establecer en la norma siguiente un círculo amplio de sujetos ${ }^{137}$. Otro elemento es la completa criminalización del problema de la violencia intrafamiliar mediante la creación del tipo de maltrato habitual.

Más fecunda en ejemplos es la Ley $\mathrm{N}^{\mathrm{o}}$ 20.480. Comenzando por la exposición de motivos de la moción parlamentaria, en que se criticó la legislación vigente por mostrarse insuficiente y generar sensación de inseguridad. Lo propio sucedía con propuestas iniciales que, pese a no incorporarlas la ley definitiva, en virtud de la crítica académica, demostraban un claro signo de populismo ${ }^{138}$. Tendencia ésta que se mantuvo durante el debate legislativo $^{139}$. Detrás del recurso al neologismo femicidio, término de rápida asimilación en el ciudadano y los medios de comunicación, late igualmente un simbolismo patente, pues la diferencia semántica no se reproduce en el marco penal. Y, en general, expresiva de esta nota es la técnica legislativa que embiste un desafío social insuperable por la vía punitiva, con el fin de rescatar el prestigio resolutivo del Estado ${ }^{140}$.

Un plexo de consecuencias adversas hace del Derecho penal simbólico un fenómeno indeseable. La primera y más clara es el apartamiento del principio de ofensividad, cuestión ya advertida para el caso de parricidios y femicidios en relaciones fenecidas. De otro lado, esta tendencia presenta la peligrosa imagen de un Derecho punitivo que asume propósitos de pedagogía social que no le corresponden ${ }^{141}$; porque, aunque castigue hechos individuales que encierran problemas generales, no es función suya corregir las fuentes primarias de conflicto. A lo dicho súmase también el riesgo de generar sensaciones de desaprobación en la ciudadanía respecto de un Derecho penal que no cumple la finalidad preventiva que promete $^{142}$, o peor aún, cierta resignación en los poderes públicos, que tras confirmar la ineficacia de su mecanismo más contundente, vean en éste un problema irremediable. Y es que contener la alarma social mediante el ius puniendi podrá ser políticamente rentable para quien elabora las leyes, mas asolador para la racionalidad, justicia y eficacia del sistema ${ }^{143}$.

\footnotetext{
${ }^{136}$ El destacado en cursiva es nuestro.

${ }^{137}$ Contraste que advierte CORCOY BIDASOLO, "Problemática", cit. nota no 18, p. 308.

${ }^{138}$ Sobre ambos puntos nos remitimos al primer apartado de este trabajo.

${ }^{139}$ La Comisión de Familia, por ejemplo, informó que "era urgente enviar una señal clara a la sociedad", mientras la Comisión Mixta señaló que "la tipificación y sanción del femicidio no terminará con el problema, pero ayudará a visualizar el tema”.

${ }^{140}$ Destacando en términos negativos el principio de autoridad que subyace a esta especie de normas y la protección de un bien jurídico formal, dado por el interés de tutela del Estado, véase CUESTA PASTOR, Pablo, "Delitos de violencia de género y violencia habitual en el ámbito doméstico", Cuadernos de Política Criminal, n ${ }^{\circ} 109$ (2013), pp. 147-173, p. 173. De igual modo críticos al respecto, ZAFFARONI/ALAGIA/ SLOKAR, Manual de Derecho penal, cit. nota $\mathrm{n}^{\circ}$ 46, p. 270.

${ }^{141}$ En este sentido, CARNEVALI RODRÍGUEZ, Raúl, "Derecho penal como ultima ratio. Hacia una Política criminal racional”, Ius et Praxis, vol. XIV, no 1 (2008), pp. 13-48, p. 37. Cfr. también GARCÍA-PABLOS, Antonio, Introducción al Derecho penal, $3^{\mathrm{a}}$ ed., Madrid: Centro de Estudios Ramón Areces, 2005, p. 199.

142 CARNEVALI, "Derecho penal como ultima ratio", cit. nota $n^{\circ} 141$, p. 37. En similar tono, SILVA SÁNCHEZ, Aproximación, cit. nota nº 67, p. 485.

${ }^{143}$ Cfr. MUSCO, Enzo, "La irracionalidad en el Derecho penal", Revista Electrónica de Ciencia Penal y Criminología, Trad.: FAGGIANI, Valentina, no 16 (2014), p. 3, en: http://criminet.ugr.es/recpc/16/recpc16-
} 
GONZÁLEZ, Diego. "El delito de parricidio: consideraciones críticas sobre sus últimas reformas".

\subsection{Otras consideraciones político-criminales.}

En opinión de algunos, el empleo de neologismos como el femicidio, permite establecer diferencias a nivel estadístico, evitando así su confusión con otras hipótesis de parricidio o su reducción a meros hechos aislados ${ }^{144}$. Pero, dejando a un lado esta ventaja tangencial, es difícil negar que existen varios aparatos de reacción contra la llamada violencia de género, y que de ellos, probablemente, el Derecho penal haya demostrado ser el menos útil ${ }^{145}$.

En términos generales, la ineficacia de los preceptos penales, tanto en éste como en otros conflictos de alcance social, se explica a partir de la desatención que sufren los ámbitos primarios que las gestan ${ }^{146}$. En el caso que nos ocupa, la influencia ejercida por un condicionamiento cultural intenso, de antiguo asociado a patrones de conducta propios de la sociedad patriarcal ${ }^{147}$, determina que las soluciones correctas de cara al aciago fenómeno, necesariamente, deban situarse primero en un plano valorativo. Las formas atávicas de entender el respeto y la obediencia entre padres e hijos, o la ausencia de un sentido mínimo de tolerancia e igualdad en las relaciones de pareja, son disfunciones prefiguradas en el seno mismo de las relaciones familiares, donde poco puede hacer una intervención penal postrera. En consecuencia, las principales estrategias preventivas dicen relación con medidas de carácter educacional, especialmente las impartidas a niños en su más temprana edad, cuando forjan sus primeras ideas en torno a la licitud y corrección de su actuar ${ }^{148}$. En el análisis de este problema suelen sugerirse, además, otras alternativas de muy diverso cariz - medidas en el ámbito económico y laboral, órdenes de alejamiento, tratamientos psicológicos, programas terapéuticos para controlar adicciones, etc.-, dada la multiplicidad de factores que lo envuelven ${ }^{149}$. Con todo, muchas de éstas ya existen en la legislación actual, y aunque realmente se aplicasen, sería ilusorio ver en ellas la panacea si no están acompañadas de cambios estructurales, harto más complejos y de largo aliento.

r1.pdf [visitado el 01.11.2014], para quien "esta contradicción de la esencia del derecho de penar con su misma existencia, se traduce en una crisis no solo política sino también ontológica y epistemológica".

${ }^{144}$ LAURENZO, “Apuntes sobre el feminicidio", cit. nota n 23, p. 141.

${ }^{145}$ Efectos vanos de una política legislativa, que cifra sus esfuerzos desde un prisma estrictamente punitivo, se rastrean en Holanda hasta varias décadas atrás. Cfr. BERGALLI, Roberto; BODELÓN, Encarna, "La cuestión de las mujeres y el Derecho penal simbólico", Anuario de Filosofía del Derecho, vol. IX (1992), pp. 43-73, pp. 63 y ss., quienes comentan que en dicho país, durante los años setenta, un movimiento feminista reaccionó contra la violencia sexual, reclamando del Estado mayor intervención. No obstante, después de diez años, las mismas representantes se decían defraudadas por un sistema en el cual la criminalización del asunto terminó por restringir su significado inicial, situándolo en un plano meramente individual: el del delito.

${ }_{146}$ Cfr. HIRSCH, Hans-Joachim, Obras completas, t. II, Buenos Aires: Rubinzal-Culzoni, 2000, p. 81.

147 Así, LAURENZO, “Apuntes sobre el feminicidio", cit. nota n 23, p. 120. Una interpretación diversa de este apuro lo presenta como defecto en el reparto de roles en la estructura familiar, donde unos sujetos ejercen el papel de controladores y otros el de sometidos, con independencia de su sexo. Véase al respecto, NÚÑEZ, Elena, "La violencia doméstica en la legislación española: especial referencia al delito de maltrato habitual (art. 173.2 del Código penal)", Revista de Estudios de la Justicia, no 12 (2010), pp. 95-146, p. 102.

${ }^{148}$ CORN, "Il femminicidio", cit. nota no 35, p. 11. Lo dicho, sin embargo, puede predicarse respecto de la mayoría de los ámbitos de la criminalidad. En este sentido, MUÑOZ CONDE, Francisco, Derecho penal y control social, $2^{a}$ ed., Bogotá: Temis, 2004, p. 27, nos recuerda que la conciencia moral, el superyó y la ética social, se forman desde la niñez en referencia primariamente a situaciones y comportamientos de otras personas, y sólo secundariamente en referencia a las normas penales.

${ }^{149}$ Así, BUSTOS, Juan, Obras completas, t. III, 2a ed., Santiago: Ediciones Jurídicas de Santiago, 2009 , p. 95. 
Polít. crim. Vol. 10, № 19 (Julio 2015), Art. 7, pp. 192-233.

[http://www.politicacriminal.cl/Vol_10/n_19/Vol10N19A7.pdf]

Existen casos en que ni siquiera la posición de la víctima puede definirse con claridad. Así, en contextos de maltrato intrafamiliar es de sólita ocurrencia que ella misma preste su consentimiento o coopere para que el agresor quebrante una prohibición de acercamiento. Acaso este dato revela que las víctimas no siempre están interesadas en la aplicación de penas altas, sino en el cese de tales ofensas o en la rehabilitación efectiva de su agresor ${ }^{150}$.

Por otro lado, que los incrementos de pena carecen de efectos disuasivos es una idea bastante extendida. No obstante, el argumento parece reforzarse en estos delitos, donde el hechor desconoce tal agravación, o enterado de ella, es poco probable que sirva para refrenar las maquinaciones criminales de quien alcanzó el paroxismo. Quizás luego discurra sobre una explicación para su conducta, que, posiblemente, preferirá ver como ajena. Nada raro, sin embargo, será que el sujeto opte por suicidarse o que se entregue voluntariamente a la justicia, con lo cual revela plena conciencia sobre la ilicitud de su comportamiento ${ }^{151}$.

Para cerrar, anotemos que las estadísticas de femicidios perpetrados durante los últimos años en Chile parecen mantenerse invariables ${ }^{152}$.

\section{Conclusiones.}

El parricidio debe derogarse. Desde hace décadas el mayor reproche atribuido al parricida fue cediendo paso ante la comprensión de que generalmente tales hechos de sangre tienen lugar en familias averiadas, mediando contextos de abuso, maltrato o arrebatos. Y, aunque el fundamento técnico del delito puede encontrarse en su carácter pluriofensivo, no nos parece razonable un aumento tan significativo de la pena, ni mucho menos que la agravación opere de modo automático. Más bien, el efecto modificador del parentesco debería evaluarse, como modernamente se hace, en los términos de una circunstancia mixta. Late tras esta idea un principio de equidad, inspirado en no medir con una misma vara realidades que pueden ser infinitamente dispares; para que sean las características del caso concreto, y no el legislador, a priori, las que determinen la gravedad del hecho.

El artículo 390 no sólo mantiene el arcaico delito, sino que amadriga en él figuras harto diversas entre sí. La inclusión de concubinarios y, sobre todo, de vínculos fenecidos, nos ofrece una figura asaz extraña a su comprensión histórica y dogmática, en la que ya el uxoricidio se veía desde hace tiempo como un cuerpo ajeno.

La falta endémica de una regulación del concubinato en Chile es un serio problema, pues su situación en la doctrina y la jurisprudencia no es tan pacífica como se cree. Dicha cuestión debe conducir también a reflexionar sobre la desatención que en general sufre el principio de determinación de las leyes penales. El restringido ámbito de aplicación del proyecto de

${ }^{150}$ Cfr. CARNEVALI, "Derecho penal como ultima ratio", cit. nota $\mathrm{n}^{\mathrm{o}}$ 141, p. 37.

${ }^{151}$ Cfr. STANGELAND, Per, "Malos tratos y homicidios en la pareja: una visión intercultural", Revista de Derecho penal y Criminología, no 15 (2005), pp. 241-260, p. 255.

152 Según la información proporcionada por el Servicio Nacional de la Mujer, los femicidios registrados durante los años 2011, 2012, 2013 y 2014, ascienden a 40, 34, 40 y 40, respectivamente. Véase: http://portal.sernam.cl/?m=programa\& $\mathrm{i}=67$. 
GONZÁLEZ, Diego. "El delito de parricidio: consideraciones críticas sobre sus últimas reformas".

Ley de acuerdo de unión civil, que sólo alcanza a parejas registradas, mantendrá a la deriva la situación de aquellos que mantengan un concubinato no formalizado.

Más grave todavía resulta la inclusión de ex cónyuges y ex concubinarios. Aquí derechamente se prescinde de la ofensa a un bien jurídico suplementario a la vida del paciente, por ende, la pena no puede menos que resultar abiertamente desproporcionada. El posible fundamento de las hipótesis tradicionales de parricidio queda en estos eventos totalmente desdibujado. 
Polít. crim. Vol. 10, No 19 (Julio 2015), Art. 7, pp. 192-233.

[http://www.politicacriminal.cl/Vol_10/n_19/Vol10N19A7.pdf]

\section{BIBLIOGRAFÍA}

ALIMENA, Bernardino, Delitos contra la persona, Bogotá: Temis, 1975.

ALONSO ÁLAMO, Mercedes, "Protección penal de la igualdad y derecho penal de género", Cuadernos de Política Criminal, no 95 (2008), pp. 19-52.

ÁLVAREZ PRIETO, Luis, "La violencia de género en España y su repercusión jurídica", Revista general de Derecho canónico y Derecho eclesiástico del Estado, nº 4 (2004), en: $\quad$ http://www.iustel.com/v2/revistas/detalle_revista.asp?id_noticia $=402152$ [visitado el 12.11.2014].

AROCENA, Gustavo; CESANO, José, El delito de femicidio: aspectos político-criminales y análisis dogmático-jurídico, Buenos Aires-Montevideo: B de F, 2013.

BACIGALUPO, Enrique, Principios de Derecho penal, $4^{\mathrm{a}}$ ed., Madrid: Akal, 1997.

BAJO FERNÁNDEZ, Miguel, El parentesco en el Derecho penal, Madrid: Universidad Autónoma de Madrid, 1972.

BALMACEDA HOYOS, Gustavo, Manual de Derecho penal: Parte especial, Santiago: Librotecnia, 2014.

BARRIENTOS, Javier, De las uniones de hecho: legislación, doctrina y jurisprudencia, Santiago: LexisNexis, 2008.

2011.

Derecho de las personas: Derecho matrimonial, Santiago: LegalPublising,

,'Sobre la noción de 'conviviente' utilizada en el artículo 390 del Código penal", Revista Chilena de Derecho Privado, no 7 (2006), pp. 191-233.

BERGALLI, Roberto; BODELÓN, Encarna, "La cuestión de las mujeres y el Derecho penal simbólico", Anuario de Filosofía del Derecho, vol. IX (1992), pp. 43-73.

BULLEMORE, Vivian; MACKINNON, John, Curso de Derecho penal, t. III, Santiago: LexisNexis, 2005.

BUSTOS RAMÍREZ, Juan, Manual de Derecho penal: Parte especial, $2^{\mathrm{a}}$ ed., Barcelona: Ariel, 1991.

, Obras completas, t. III, $2^{\mathrm{a}}$ ed., Santiago: Ediciones Jurídicas de Santiago, 2009.

BUSTOS RAMÍREZ, Juan; HORMAZÁBAL, Hernán, Lecciones de derecho penal, vol. I, Madrid: Trotta, 1997.

CARNEVALI RODRÍGUEZ, Raúl, "Derecho penal como ultima ratio. Hacia una Política criminal racional", Ius et Praxis, vol. XIV, n 1 (2008), pp. 13-48.

CARRARA, Francesco, Programa de Derecho criminal, t. III, $2^{\mathrm{a}}$ ed., Trad.: ORTEGA, J., Bogotá: Temis, 1967.

CEREZO MIR, José, Curso de Derecho penal español: Parte general, t. II, $6^{\text {a }}$ ed., Madrid: Tecnos, 2000.

CORCOY BIDASOLO, Mirentxu, "Problemática jurídico-penal y político-criminal de la regulación de la violencia de género y doméstica", Revista de Derecho (Valparaíso), n' XXXIV (2010), pp. 305-347.

CORN, Emanuele, 'Il 'femminicidio' come reato. Spunti per un dibattito italiano alla luce dell'esperienza cilena", Diritto Penale Contemporaneo, 22 pp., en: http://www.penalecontemporaneo.it/upload/1379085952CORN\%202013a.pdf [visitado el 08.11.2014]. 
GONZÁLEZ, Diego. "El delito de parricidio: consideraciones críticas sobre sus últimas reformas".

, "La revolución tímida. El tipo de femicidio introducido en Chile por la Ley No 20.480 desde una perspectiva comparada", Revista de Derecho de la Universidad Católica del Norte, $\mathrm{n}^{\mathrm{o}} 2$ (2014), pp. 103-136

CUESTA PASTOR, Pablo, "Delitos de violencia de género y violencia habitual en el ámbito doméstico", Cuadernos de Política Criminal, n ${ }^{\circ} 109$ (2013), pp. 147-173.

CURY URZÚA, Enrique, Derecho penal. Parte general, $7^{\mathrm{a}}$ ed., Santiago: Ediciones Universidad Católica de Chile, 2005.

DEL ROSAL, Juan; COBO, Manuel; RODRÍGUEZ MOURULLO, Gonzalo, Derecho penal español, t. III, Madrid: Imprenta Aguirre, 1962.

DEL VILLAR BRITO, Waldo, Manual de Derecho penal: Parte especial, Valparaíso: Edeval, 2009.

DÍEZ RIPOLLÉS, José Luis, "El Derecho penal simbólico y los efectos de la pena", Boletín mexicano de Derecho comparado, vol. XXXV, no 103 (2002), pp. 63-97.

DÍEZ RIPOLLÉS, José Luis; GRACIA MARTÍN, Luis, Delitos contra bienes jurídicos fundamentales: vida humana independiente y libertad, Valencia: Tirant lo Blanch, 1993.

DONNA, Edgardo, Derecho penal: Parte especial, t. I, $3^{\mathrm{a}}$ ed., Buenos Aires: RubinzalCulzoni, 2008.

DONOSO, Florencia; RIOSECO, Andrés, El concubinato ante la jurisprudencia chilena, Santiago: LexisNexis, 2007.

ESPINOZA, Edilberto, “Se debe suprimir el parricidio del Código penal peruano?”, Revista jurídica del Perú, nº 61 (2005), pp. 77-91.

ETCHEBERRY, Alfredo, Derecho penal: Parte especial, t. III, $3^{\text {a }}$ ed., Santiago: Editorial Jurídica de Chile, 1997.

FERNÁNDEZ CRUZ, José Ángel, "Principalismo, garantismo, reglas y derrotabilidad en el control de constitucionalidad de las leyes penales", Revista de Ciencias Penales, vol. XLI, no 3 (2014), pp. 91-114.

FIANDACA, Giovanni; MUSCO, Enzo, Diritto penale: Parte generale, Quinta edizione, Bologna: Zanichelli, 2007.

FIGUEIREDO DIAS, Jorge, “Artigo 132”, en: FIGUEIREDO DIAS, Jorge (Dir.), Comentário Conimbricense do Código Penal, t. I, Coimbra: Coimbra Editora, 1999, pp. 24-46.

GANZENMÜLlER, Carlos; ESCUDERO, José; FRIGOLA, Joaquín, Homicidio y asesinato, Barcelona: Bosch, 1996.

GARCÍA-PABLOS, Antonio, Introducción al Derecho penal, $3^{\mathrm{a}}$ ed., Madrid: Centro de Estudios Ramón Areces, 2005.

GARRIDO MONTT, Mario, Derecho penal: Parte especial, t. III, $4^{\mathrm{a}}$ ed., Santiago: Editorial Jurídica de Chile, 2010.

GROIZARD, Alejandro, Código penal de 1870, concordado y comentado, t. IV, Salamanca: Esteban Hermanos Impresores, 1897.

GRÜNHUT, Max, "Formación de conceptos y aplicación del Derecho en el Derecho penal”, Anuario de Filosofía jurídica y social, Trad.: GUZMÁN DALBORA, José Luis, no 22 (2004), pp. 307-329.

GUALLART DE VIALA, Alfonso, "Parricidio", en: Nueva Enciclopedia Jurídica, t. XVIII, Barcelona: Seix, 1986, pp. 927-944. 
Polít. crim. Vol. 10, № 19 (Julio 2015), Art. 7, pp. 192-233.

[http://www.politicacriminal.cl/Vol_10/n_19/Vol10N19A7.pdf]

GUZMÁN DALBORA, José Luis, Figuras y pensamientos del Derecho penal contemporáneo, Montevideo-Buenos Aires: B de F, 2014.

HASSEMER, Winfried, "Derecho penal simbólico y protección de bienes jurídicos", en: BUSTOS, Juan (Dir.), Pena y Estado, Santiago: Conosur, 1995, pp. 23-36.

HERNÁNDEZ BASUALTO, Héctor, "La definición de 'convivencia' en el art. 390 del Código penal", Informes en Derecho. Doctrina procesal penal 2010, nº 8 (octubre, 2011), pp. 47-52.

HIRSCH, Hans-Joachim, Obras completas, t. II, Buenos Aires: Rubinzal-Culzoni, 2000.

ÍÑIGO, Elena, "Fundamento del efecto modificador de la responsabilidad penal de la relación de parentesco", InDret, no 4 (2011), 28 pp.

JESCHECK, Hans-Heinrich; WEIGEND, Thomas, Tratado de Derecho penal: Parte general, Trad. de la $5^{\mathrm{a}}$ ed. alemana: OLMEDO, M., Granada: Comares, 2002.

JIMÉNEZ DE ASÚA, Luis, Tratado de Derecho penal, t. III, $4^{\mathrm{a}}$ ed., Buenos Aires: Losada, 1963.

KINDHÄUSER, Urs, "Hechos brutos y elementos normativos del tipo", Trad.: DE LA VEGA, O., InDret, $\mathrm{n}^{\mathrm{o}} 2$ (2014), 25 pp.

LABATUT, Gustavo, Derecho Penal, t. II, $7^{\text {a }}$ ed., actualizada por ZENTENO, Julio, Santiago: Editorial Jurídica de Chile, 1996.

LARRAURI, Elena, Criminología crítica y violencia de género, Madrid: Trotta, 2007.

LAURENZO, Patricia, "Apuntes sobre el feminicidio", Revista de Derecho penal y Criminología, $\mathrm{n}^{\circ} 8$ (2012), pp. 119-143.

LAZCURAÍN, Juan Antonio, "El control constitucional de las leyes penales", en: VELÁSQUEZ, Fernando; VARGAS, Renato (Compiladores), Derecho penal y Constitución, Bogotá: Universidad Sergio Arboleda, 2014, pp.11-44.

LÓPEZ DÍAZ, Carlos, Manual de Derecho de familia y tribunales de familia, t. I, Santiago: Librotecnia, 2005.

MANTOVANI, Ferrando, Diritto Penale: Parte generale, Sesta edizione, Padova: Cedam, 2009.

MAÑALICH, Juan Pablo, Terror, pena y amnistía, Santiago: Flandes Indiano, 2010.

MAQUEDA, María Luisa, "La violencia de género. Entre el concepto jurídico y la realidad social", RECPC, $n^{o} 2$ (2006), 13 pp., en: http://criminet.ugr.es/recpc/08/recpc0802.pdf [visitado el 12.11.2014].

MATUS, Jean Pierre; RAMÍREZ, María Cecilia, Lecciones de Derecho penal chileno: Parte especial, t. I, $3^{\mathrm{a}}$ ed., Santiago: LegalPublishing, 2014.

MEDINA JARA, Rodrigo, Manual de Derecho penal: Parte especial, Santiago: LexisNexis, 2007.

MERA FIGUEROA, Jorge, "Femicidio", en: RED CHILENA CONTRA LA VIOLENCIA DOMÉSTICA Y SEXUAL, Tipificación del femicidio en Chile: un debate abierto, Santiago: Red Chilena contra la violencia doméstica y sexual, 2009, pp. 53-57.

MIR PUIG, Santiago, Derecho penal: Parte general, $7^{\mathrm{a}}$ ed., Barcelona: Repertor, 2005.

MORALES PRATS, Fermín, "Del homicidio y sus formas", en: QUINTERO OLIVARES, Gonzalo (Dir.), Comentarios a la Parte especial del Derecho penal, $6^{a}$ ed., Navarra: Aranzadi, 2007, pp. 31-83.

MORILLAS, Lorenzo, "Valoración de la violencia de género desde la perspectiva del Derecho penal", RECPC, $\mathrm{n}^{\mathrm{o}} 4$ (2002), 23 pp., en: http://criminet.ugr.es/recpc/recpc 04-06.pdf [visitado el 02.11.2014]. 
GONZÁLEZ, Diego. "El delito de parricidio: consideraciones críticas sobre sus últimas reformas".

MUÑOZ CONDE, Francisco, Derecho penal: Parte especial, Sevilla: Publicaciones de la Universidad de Sevilla, 1976. , Derecho penal y control social, $2^{\mathrm{a}}$ ed., Bogotá: Temis, 2004.

MUSCO, Enzo, "La irracionalidad en el Derecho penal", Revista Electrónica de Ciencia Penal y Criminología, Trad.: FAGGIANI, Valentina, no 16 (2014), 15 pp., en: http://criminet.ugr.es/recpc/16/recpc16-r1.pdf [visitado el 01.11.2014].

NOVOA MONREAL, Eduardo, Curso de Derecho penal chileno, t. I, $2^{\circ}$ ed., Santiago: Editorial Jurídica Ediar, 1985.

NÚÑEZ, Ricardo, Tratado de Derecho penal, t. III, Córdoba: Lerner, 1978.

NÚÑEZ CASTAÑO, Elena, "La violencia doméstica en la legislación española: especial referencia al delito de maltrato habitual (art. 173.2 del Código penal)", Revista de Estudios de la Justicia, no 12 (2010), pp. 95-146.

OLIVER CALDERÓN, Guillermo, Retroactividad e irretroactividad de las leyes penales, Santiago: Editorial Jurídica de Chile, 2007.

OSSANDÓN, María Magdalena, "La faz subjetiva del tipo de parricidio", Revista de Derecho (Valparaíso), n' XXXIV (2010), pp. 415-457. , La formulación de tipos penales: Valoración crítica de los Instrumentos de

Técnica Legislativa, Santiago: Editorial Jurídica de Chile, 2009.

PACHECO, Joaquín Francisco, El Código penal concordado y comentado, t. I, $6^{\mathrm{a}}$ ed., Madrid: Manuel Tello, 1888.

PADOVANI, Tullio, Diritto Penale, Decima edizione, Milano: Giuffrè, 2012.

PALAZZO, Francesco, Corso di Diritto Penale: Parte generale, Terza edizione, Torino: Giappichelli, 2008.

, "La legalidad y la determinación de la ley penal: el significado lingüístico, la interpretación y el concepto de la regla iuris", Revista Penal, Trad.: MELERO, Irene; BARÓN, Susana, no 25 (2010), pp. 104-116.

PERALTA, José, "Homicidios por odio como delitos de sometimiento (Sobre las razones para agravar el femicidio, el homicidio por odio a la orientación sexual y otros homicidios por odio)", InDret, no 4 (2013), 28 pp.

POLITOFF, Sergio; GRISOLÍA, Francisco, BUSTOS, Juan, Derecho penal. Parte especial: Delitos contra el individuo en sus condiciones físicas, $2^{\mathrm{a}}$ ed., Santiago; Editorial Jurídica Congreso, 2006.

POLITOFF, Sergio; MATUS, Jean Pierre; RAMÍREZ, María Cecilia, Lecciones de Derecho penal chileno: Parte especial, $2^{\mathrm{a}}$ ed., Santiago: Editorial Jurídica de Chile, 2005.

POLITOFF, Sergio, “Sentencias comentadas", RCP, t. XXIV, no 3 (1965), pp. 231-241.

PULITANÒ, Domenico, Diritto Penale, Terza edizione, Torino: Giappichelli, 2009.

QUINTANO RIPOLLÉS, Antonio, Tratado de la Parte especial del Derecho penal, $t$. I, vol. 1, $2^{\text {a }}$ ed. actualizada por GIMBERNAT, Enrique, Madrid: Revista de Derecho Privado, 1972.

RAMOS PAZOS, René, Derecho de familia, t. II, $7^{\mathrm{a}}$ ed., Santiago: Editorial Jurídica de Chile, 2010.

RIED, Nicolás, "Un delito propio. Análisis crítico de los fundamentos de la ley de femicidio", REJ, no 16 (2012), pp. 171-193.

RIVACOBA, Manuel, La retribución penal, Santiago: Conosur, 1995. 
Polít. crim. Vol. 10, № 19 (Julio 2015), Art. 7, pp. 192-233.

[http://www.politicacriminal.cl/Vol_10/n_19/Vol10N19A7.pdf]

, "Las circunstancias modificativas de la responsabilidad criminal en la teoría general del delito", en: SERRANO, Alfonso et al., Estudios de derecho penal y criminología en homenaje al Profesor José María Rodríguez Devesa, t. I, Madrid: Facultad de Derecho de la Universidad Nacional de Educación a Distancia, 1989, pp. 183-210.

, Nueva crónica del crimen, Valparaíso: Edeval, 1981.

RODRÍGUEZ COLLAO, Luis, Delitos sexuales, Santiago: Editorial Jurídica de Chile, 2004.

ROXIN, Claus, Derecho penal: Parte general, Trad. de la $2^{\mathrm{a}}$ ed. alemana: LUZÓN PEÑA, Diego-Manuel, Madrid: Civitas, 1997.

, "El principio de determinación de la ley en el Derecho penal alemán", en: VAN WEEZEL, Alex (Editor), Humanizar y renovar el Derecho penal: estudios en memoria de Enrique Cury, Santiago: LegalPublishing, 2013, pp. 109-141.

RUSSELL, Diana; RADFORD, Jill, Femicide: The politics of woman killing, New York: Twayne Publishers, 1992.

SALINERO, Sebastián, "El femicidio. Una revisión crítica", Microjuris, 16 de marzo de 2011, 27 pp. [Visitado el 10.11.2014].

SANZ MORÁN, Ángel, "Presupuestos para la reforma de los delitos contra la vida", $A D P C P$, t. XLVIII, fasc. III (1995), pp. 783-848.

SILVA SÁNCHEZ, Jesús-María, Aproximación al Derecho penal contemporáneo, $2^{\mathrm{a}}$ ed., Montevideo-Buenos Aires: B de F, 2010.

STANGELAND, Per, "Malos tratos y homicidios en la pareja: una visión intercultural", Revista de Derecho penal y Criminología, $\mathrm{n}^{\circ} 15$ (2005), pp. 241-260.

SUAY HERNÁNDEZ, Celia, "Los elementos normativos y el error", ADPCP, t. XLIV, fasc. I (1991), pp. 97-142.

TALADRÍZ, María José, "Decisiones judiciales en el ámbito penal acerca del concepto 'convivencia'", Revista de Ciencias penales, vol. XLI, no 4 (2014), pp. 79-102.

TAMARIT SUMALLA, Josep, "De las lesiones", en: QUINTERO OLIVARES, Gonzalo (Dir.), Comentarios a la Parte especial del Derecho penal, Navarra: Aranzadi, $6^{\mathrm{a}}$ ed. actualizada, 2007, pp. 101-143.

TOLEDO, Patsilí, Feminicidio, México D.F.: Organización en México del Alto Comisionado de las Naciones Unidas, 2009.

TORÍO LÓPEZ, Ángel, "Estudio de la reforma de los delitos contra la vida (parricidioasesinato)", en: RODRÍGUEZ DEVESA, José (coord.), Repercusiones de la Constitución en el Derecho Penal, Bilbao: Universidad de Deusto, 1983, pp. 77-114.

TORRES AGUILAR, Manuel, El parricidio: del pasado al presente de un delito, Madrid: Editoriales de Derecho, Madrid, 1991.

TRONCOSO, Hernán, Derecho de familia, 9ª ed., Santiago: LexisNexis, 2006.

TURNER, Susan, "La unión de hecho como institución del Derecho de familia y su régimen de efectos personales", Ius et Praxis, año 16, nº 1 (2010), pp. 85-98.

VAN WEEZEL, Alex, La garantía de Tipicidad en la Jurisprudencia del Tribunal Constitucional, Santiago: LegalPublishing, 2011.

"Lesiones y violencia intrafamiliar", Revista Chilena de Derecho, vol. XXXV, no 2 (2008), pp. 223-259.

VARGAS, Rafael, Derecho de familia, t. III, Santiago: Metropolitana, 2010. 
GONZÁLEZ, Diego. "El delito de parricidio: consideraciones críticas sobre sus últimas reformas".

VARGAS, Tatiana; SANTIBÁÑEZ, María Elena, "Reflexiones en torno a las modificaciones para sancionar el femicidio y otras reformas relacionadas (Ley $\mathrm{N}^{\mathrm{o}}$ 20.480)", Revista Chilena de Derecho, vol. 38, n 1 (2011), pp. 193-207.

VILLEGAS, Myrna, "El delito de maltrato habitual en la Ley № 20.066 a la luz del derecho comparado", Política Criminal, vol. 7, no 14 (diciembre, 2012), pp. 276-317, en: http://www.politicacriminal.cl/Vol_07/n_14/Vol7N14A2.pdf [visitado el 28.10.2014].

ZAFFARONI, Eugenio; ALAGIA, Alejandro; SLOKAR, Alejandro, Manual de Derecho penal: Parte general, $2^{\mathrm{a}}$ ed., Buenos Aires: Ediar, 2006.

ZAFFARONI, Eugenio, "El discurso feminista y el poder punitivo", en: ÁVILA, Ramiro; SALGADO, Judith; VALLADARES, Lola (Compiladores), El género en el Derecho. Ensayos críticos, Quito: V\&M Gráficas, 2009, pp. 321-334. , Tratado de Derecho penal: Parte general, t. III, Buenos Aires: Ediar, 1981.

\section{JURISPRUDENCIA CITADA}

Sentencia del Tribunal Constitucional, de 5 de agosto de 2010, Rol № 1432/09.

SCS, de 2 de septiembre de 2014, Rol No 1978/2014.

SCS, de 7 de marzo de 2012, Rol No 337/2011.

SCS, de 24 de junio de 2013, Rol No 5367/2012.

SCA de La Serena, de 8 de enero de 2007, Rol No 373/2006.

SCA de Temuco, de 3 de julio de 2012, Rol No 427/2012.

SCA de Valparaíso, de 13 de mayo de 2014, Rol No 510/2014. 